\title{
The Effects of Incomplete Employee Wage Information: \\ A Cross-Country Analysis
}

Solomon W. Polachek

and

Jun (Jeff) Xiang ${ }^{*}$

Department of Economics

State University of New York at Binghamton

Binghamton, New York 13902

(This Revision: May 2005)

\begin{abstract}
In this paper, we define a tractable procedure to measure worker incomplete information in the labor market. The procedure, which makes use of earnings distribution skewness, is based on econometric frontier estimation techniques, and is consistent with search theory. We apply the technique to eleven countries over various years, and find that incomplete information leads workers to receive on average about 30-35\% less pay than they otherwise would have earned, had they information on what each firm paid. Generally married men and women suffer less from incomplete information than the widowed or divorced; and singles suffer the most. Women suffer more from incomplete information than men. Schooling and labor market experience reduce these losses, but institutions within a country can reduce them, as well. For example, we find that workers in countries that strongly support unemployment insurance (UI) receive wages closer to their potential, so that doubling UI decreases incomplete information and results in 5\% higher wages. A more dense population reduces search costs leading to less incomplete information. A more industrial economy disseminates wage information better, so that workers exhibit less incomplete information and higher wages. Finally, we find that foreign worker inflows increase incomplete information, and at the same time reduce average wage levels, at least in the short-run.
\end{abstract}

\footnotetext{
${ }^{*}$ We are especially indebted to Hung-Jen Wang for providing a STATA version of the frontier estimation program, and to Subal Kumbhakar for valuable discussion. A version of this paper was presented at the Bar-Ilan Conference in Honor of Tikva Lecker. We thank participants of this conference for valuable comments and suggestions. All remaining errors are our own.
} 


\section{Introduction}

The paper goes back to George Stigler's $(1961,1962)$ path breaking work on incomplete information, It applies earnings function concepts along with frontier estimation techniques to devise a measure of incomplete information, which we parameterize as the degree employees end up receiving wages less than their potential, given their skills. Then, once we estimate incomplete information, we explore how institutional factors, such as unemployment insurance and foreign worker inflows, affect incomplete information across eleven countries.

Incomplete information leads workers to accept wages below what they could have attained had they full information about each potential employer's pay. ${ }^{1}$ Workers could improve their wage by prolonging job search, but information about available jobs is costly. To find a job, workers search the market, but normally terminate their search before discovering the very highest paying job available. As explained by Nelson (1970), Mortonsen (1970), McCall (1970) and others, individuals set a reservation wage, and search until offered a job at least equal to this reservation wage. On average, the higher the reservation wage the longer the search, but invariably the accepted wage is almost always less than the best possible market wage available for a person of their skill level.

Receiving a wage less than the maximum possible wage (given one's skill) is an important phenomenon because it illustrates an effect of incomplete information that arises from costly search. Collectively, over the whole economy, it reflects foregone gross national product, since so many within the economy are similarly receiving less than they could potentially earn. Therefore in the aggregate, this wage gap reflects incomplete information's cost to the economy. Measuring the effects of incomplete information is significant for at least two reasons. First, as just noted, one can gauge the overall economic losses associated with costly information. Second, having a measure of these losses, one can assess appropriate policies needed to reduce search costs, thereby increasing efficiency within the economy.

One result regarding policy seems pretty much universal in past literature: Unemployment insurance (measured by the replacement rate) subsidizes employee search, which lengthens unemployment duration (e.g., Mofiftt and Nicholson (1982) and Meyer (1990)). The resulting extra search enables workers to obtain more information and higher wages (e.g., Ehrenberg and Oaxaca, (1976)). A gigantic body of literature corroborates these findings regarding UI, both for the U.S. and other countries (e.g., Jurajda and Tannery (2003), Fourgere, Pradel, and Roger (1998), Van den Berg and van der Klaauw (2001), Micklewright and Nagy (1995), Card and Levine (1998), Beach and Kaliski (1983), Ham and Rea (1987), Arellano, Bentolila and Bover (1998), Belzil (1995) and Gonzalo, Maria Teresa Gonzalo (2002)).

This paper differs from past empirical research in three ways. First, rather than concentrate on

\footnotetext{
${ }^{1}$ Katz and Ziderman (1986) argue that incomplete information also affects the complete wage package including non-wage benefits. Given unobserved worker characteristics, employers provide specific non-wage amenities to attract worker with desired but unobserved characteristics, thereby affecting the equilibrium wage. Unfortunately we do not have sufficient data to consider non-wage fringes.
} 
unemployment duration, it examines worker wages. It focuses on the extent to which workers receive a wage less than what they could be paid based on their skill level. This focus enables the paper to get a metric defining the monetary effect (and indeed a measure of) incomplete information. Second, the paper examines incomplete information from an international perspective. Rather than examine incomplete information for one single country, it obtains measures for eleven countries over several time-periods. Third, by looking across countries, the paper is able to explain how inter-country institutional differences affect incomplete information.

In testing our model, we first corroborate past findings on unemployment insurance. We show that an employee's incomplete information is smaller where UI is a larger proportion of GDP. Then second, we test whether institutional factors lead to differences in incomplete employee information. In this context, we show that geographic considerations as well as industrial structure likely affect search costs, and hence incomplete information. Third, the paper culminates by examining how foreign migrant workers affect overall employee incomplete information. In this context, we determine that an influx of foreign workers into an economy decreases the effectiveness workers search, thereby increasing the degree of incomplete information within the labor market. ${ }^{2}$

\section{Background}

A country's distribution of wages defines the benefits of job search. The more dispersed are wages, the greater are the gains from search. Higher search gains lead to relatively higher reservation wages, which in turn leads to more search. But as a consequence, earnings dispersion narrows, and the degree of incomplete information diminishes. At the same time the amount of search is related to search costs. Individual characteristics, such as a worker's location vis-à-vis jobs or a worker's opportunity costs (which would be higher for those already at work) affect search costs. Higher search costs diminish search, leading to wider earnings dispersion.

The whole search process provides job seekers with wage (and amenity) information, but clearly information remains imperfect because search is costly. ${ }^{3}$ Creating an index of the degree of

\footnotetext{
${ }^{2}$ Beyond the scope of this paper is how institutional characteristics affect employer (as opposed to employee) incomplete information. To answer this latter question, one would need to adopt a two-tier estimation technique (Polachek-Yoon, 1987). However, at this point, the two-tier algorithm is not available to use with LIS data, since all statistical analysis must be done on the LIS computer with standard statistical software (SAS, SPSS, and STATA).

${ }^{3}$ At this point we are abstracting from life cycle considerations, particularly training and other opportunities available on the job. As will be illustrated later, the estimation procedure accounts for these factors by including life cycle variables. Differences in information between "inside" and "outside" employees may also be a consideration, but getting at these is more difficult. Not all "inside" information is acted upon, and hence it is more difficult to measure. For example, the perspicacious peregrinator (Polachek-Horvath, 1977) searches on-the-job for more beneficial opportunities. The information he/she gathers is unobservable until acted upon, which doesn't occur until the perspicacious peregrinator actually moves.
} 
incomplete information is important because, as already mentioned, incomplete information leads to lost opportunities and diminished GNP. But in addition, the level of incomplete information is an indicator of market competition. Whereas prices collapse to a unique single equilibrium in purely competitive full-information markets, this is not the case in imperfect competition where there are multiple prices. But even markets for homogeneous easily transferable commodities contain price variability when there is imperfect information.

The amount of market imperfection can also be related to institutional factors. These institutions might include information networks, such as nationally based bargaining units (e.g., Germany) and the availability of unemployment insurance (most developed countries), but they also could include other institutions, such as inflows of foreign workers (who might have little information) into an economy. There is much research on how migrants affect the labor market. These analyses include the effect of immigrants on wages. Some of this research looks at how quickly (in terms of number of generations) migrants achieve success equal to natives (Chiswick, 1978). Other of this research examines how this rate of assimilation depends on migrant quality, particularly concentrating on the skills migrants possess upon entering a country (Borjas, 1985). However, almost no research assesses workers' overall knowledge of wage offer distributions. Similarly, almost no research assesses the effects of foreign workers on incomplete information within a particular labor market. This paper examines both. It develops a metric defining the effects of incomplete information. It assesses the impact of institutional factors including unemployment insurance and population density. It assesses how in-migration of foreign workers affects the amount of information workers have regarding the labor market. All this is done with international labor market data on eleven countries obtained from the Luxembourg Income Study (LIS).

Incomplete Information

There is a large literature on the theory of equilibrium prices. Most is theoretical, and most concerns defining the conditions under which there is an equilibrium price distribution (e.g., Reinganum (1979), Burdett and Judd (1983), Bester (1986), Arnold (2000), and Kamiya and Sato (2004)). There is also a small but growing body of literature that is empirical. That literature relies on overall price variation to measure the degree if incomplete information (e.g., Stigler (1961), Stigler and Kindahl (1970), Lach and Tsiddon (1992), and Sorensen (2000)).

As recognized by Stigler and others, there is a major drawback of merely using price (or wage) dispersion as a measure of incomplete information. Price dispersion can vary for many reasons other than incomplete information. These include differences in worker quality, differences in worker-firm bargaining power such as through unions, but they also can result from noisy data. Dispersion measures do not get at these considerations because they don't net out these effects. Regression models suffer the same biases because the dispersion measures they use as the dependent variable do not net out random price variations, nor do they distinguish between a worker's (seller's) and a firm's (buyer's) incomplete information. Thus these past more traditional measures do not reflect accurate estimates of incomplete information.

One technique to get at incomplete information that can net out worker quality as well as pure 
measurement error, yet get a measure of the effect of incomplete employee information, is given in Hofler-Polachek (1985), and Polachek-Yoon (1987). The technique is relatively simple to implement. Basically, it measures worker incomplete information as a parameter obtained from estimating an earnings function using frontier estimation techniques. Essentially, this parameter depicts the degree workers receive wages that are less than they could obtain, had they known the specific firms paying the highest wages. Hofler and Murphy (1992) employ this technique to compute the average worker shortfall using the 1983 U.S. Current Population Survey (CPS). Gaynor and Polachek (1994) apply the technique to compute incomplete information about physician prices. Daneshvary et al. (1992) use the technique to get at assimilation of foreign workers in the U.S., and Lang (2004) uses it to get at assimilation of German immigrants. Groot and Oosterbeek (1994) corroborate the validity of the approach using a 1985 Dutch national sample of employees. Finally Polachek and Robst (1998) confirm the technique's power by showing how the technique's incomplete information measures match those independently obtained from the World of Work test administered to a group of workers in the 1966U.S.National Longitudinal Survey of Young Men (NLSYM).

But to date, no one has systematically studied how the degree of incomplete information differs across countries. Part of the problem is the paucity of data for enough countries to be able to draw valid conclusions. Comparative cross-country micro-data were simply not available. However, new data are now obtainable from the Luxembourg Income Study (LIS) for a sufficient number of countries to get meaningful results. This paper applies the techniques mentioned above to estimate the amount of employees' incomplete information. It then looks at different institutional factors across countries to determine how these institutional factors affect incomplete information.

Approach

We use Luxembourg Income Study (LIS) data to examine incomplete information by country. The LIS is a collection of household data compiled from ongoing statistical surveys in approximately 29 countries widely spread across Europe, America, Asia and Oceania. The data are standardized in order to facilitate comparative research. The LIS began in 1983 and is now jointly sponsored by the Luxembourg government and the Centre for Population, Poverty and Policy Studies (CEPS), the Centre Universitaire (CU) de Luxembourg.

Data include country-specific labor force surveys over various labor market structures. These data provide demographic, income and expenditure information on three different levels: household, person and child. We concentrate on extracting earnings, education and age data from the LIS person files for ten OECD countries, and Israel.

For each country we use an econometric frontier estimation technique developed by Aigner, Lovell and Schmidt (1977) and Meeusen and van den Broeck (1977), originally employed by Hofler and Polachek (1985) to estimate a numeric index of incomplete worker information. Next we look at institutional factors within countries to establish which of these institutions affect incomplete information. First standard institutions such as UI are considered. Then, we concentrate on population density, the proportion of rural employment, the proportion of industrial employment, 
and finally the influx of foreign workers into an economy.

\section{Modeling Incomplete Information}

Assume a labor market with a wage offer distribution such that wages for a worker of given skill

vary from a low of $w_{\min }$ to a maximum of $w_{\max } \cdot{ }^{4} \mathrm{~A}$ worker entering this job arena is motivated to seek a job at the firm paying the highest possible wage. The only problem is that the worker does not know which firms pay high wages. Indeed, given that firm heterogeneity is not uniform across jobs (so that some firms may pay high wages for one particular skill, but low wages for another), wages vary across firms in uneasy to detect ways, a priori. Given this incomplete information, the worker must search. To do this, the worker sets a reservation wage $w_{i}^{R}$, which is the minimum wage the worker will accept when searching. This reservation wage is based on perceived costs and benefits of search. On average, a worker searches more the higher the reservation wage, and less the lower the reservation wage. The greater the search, the more likely the worker achieves a wage closer to the maximum $w_{\max }$.

Suppose worker $i$ finds a job paying a wage $w_{i}^{0}$, such that $w_{\max } \geq w_{i}^{0} \geq w_{i}^{R}$. The gap between $w_{\max }$ and $w_{i}^{0}$ will vary across individuals, depending upon relative success in the worker's job search. The greater one's knowledge of the labor market the more likely the chance $w_{i}^{0}$ is closer to $w_{\max }$, barring the impact of luck (which we'll talk about shortly). Let $u_{i}$ be the (logarithmic) gap between $w_{\max }$ and the wage one actually receives $\left(w_{i}^{0}\right)$. This gap represents the proportion by

\footnotetext{
${ }^{4}$ Wage level $w$ is dependent on the worker's skill level $x$ and a variable $\theta$ that will be defined shortly, so that $w=w(x, \theta)$. This wage can vary somewhat because companies differ in how they use comparably skilled workers. Some, perhaps with good management and/or higher physical capital (both indexed by $\theta$ ) pay more, while other less efficient companies pay lower amount for comparable workers. This results in a distribution of potential wages, for example $\mathrm{W} \sim \mathrm{N}(\bar{w}, \theta)$, given the firms' heterogeneity of utilization of workers of given quality $x$. Accordingly, there are high wage firms, the maximum wage being $w_{\max }(x)$, and low wage firms, the minimum being $w_{\min }(x)$. For now, since we are talking about a worker of a particular skill level, we suppress the vector of worker characteristics (x), defining these available wages as $w_{\min }$ and $w_{\max }$.
} 
which one could enhance one's current wage through continued search for the highest possible wage.

The variable $u_{i}$ can be expressed as

$$
u_{i}=\ln w_{\max }-\ln w_{i}^{0}+\omega_{i}
$$

and reflects the cost to a worker of incomplete information. In (1) $\omega_{i}$ reflects luck, which for the sake of assumption can be normally distributed with zero mean. The average $u=\sum_{i} u_{i} / N$, over all workers $(\mathrm{N})$ in the market, depicts the mean effect of worker incomplete information. Note that since $E\left(\omega_{i}\right)=0$ luck cancels out when computing average incomplete information for all workers.

Using similar logic, a firm pays more than necessary to the $\mathrm{i}^{\text {th }}$ worker, since it pays $w_{i}^{0}$ despite the worker's willingness to work at $w_{i}^{R}$. The gap $\left(\ln w_{i}^{0}-\ln w_{i}^{R}\right) \geq 0$ reflects the effect of the firm's incomplete information regarding worker $i$ (neglecting luck). But, in reality, worker $i$ need not be the lowest reservation waged worker, so that the true effect of the firm's incomplete information is $\eta_{i}=\ln w_{i}^{0}-\ln w_{\min }$, where $w_{\min }$ is the minimum reservation wage for all comparable workers who satisfy the job's requirements. The average $\eta=\sum_{i} \eta_{i} / N$, across all workers (N), depicts the mean effect of firm incomplete information.

Polachek and Yoon (1987) tested search theory's implications by computing average $u$ and $\eta$ for various groups of workers. They used the Panel Study of Income Dynamics (PSID) for the U.S. in 1981, and found smaller $u$ values for workers who received UI benefits before their current job. This finding illustrated the efficiency UI brings about through enhanced worker search. Similarly, using the January 1983 Current Populations Survey (CPS), Hofler and Murphy (1992: 516) found that workers in areas paying relatively higher unemployment benefits exhibit a smaller $u$. Groot and Oosterbeek (1994) found that "males have more labor market information than females [which is] probably caused by the greater market attachment of males, which makes the opportunity costs of ignorance [i.e., incomplete information] greater for males than females (p. 388)." They also found that "employees in the public sector possess more market information than workers in the private sector ... probably due to the fact that wage policies in the private sector are in general less public knowledge and more individually based (p. 388)." Polachek and Robst (1998) found that workers scoring high on World of Work tests had more information than those with lower World of Work scores. Finally Gaynor and Polachek (1994) applied the technique to the medical profession, and there too found that "measured incomplete information is higher when ... search costs are higher (p.830)." But to date no one has done a comprehensive study across more than one country. 
Nor have they examined whether in-migration affects incomplete information.

\section{Estimation Procedure}

The LIS data require all computations be done on the Luxembourg computer. At this time limitations on canned STATA and SAS software preclude estimating both employer and employee information simultaneously. However, Groot and Oosterbeek (1994) find employer incomplete information to be relatively constant across economic sectors, as does Polachek and Yoon (1987). This result means that incomplete employee information varies far more than incomplete employer information. So, because incomplete employer information varies little with institutional characteristics, we concentrate solely on incomplete worker information $\left(u_{i}\right)$.

To put meat on the discussion, we now derive the econometric specification. However, first a word regarding the underpinnings of an individual's maximum possible wage, $w_{\max }(x)$ defined earlier in footnote 4. Various models can describe the underlying factors of an individual's wage potential. For example, the human capital model argues that a worker's wage potential is determined by human capital acquisition. Productivity enhancing contract models suggest contracts whereby a worker's ability to supply effort affects wage. Finally, collective bargaining implies that union power is important when negotiating a viable contract. Each of these underpinnings can be represented by a vector of an employee's own individual and his or her firm's characteristics, which we denote as vector $x_{i}{ }^{5}$ As such, a worker's maximum potential wage $\left(w_{i}^{p}\right)$ is related to $X_{i}$, plus measurement error. ${ }^{6}$ In logarithmic form,

$$
\left.\ln w_{\max }\right|_{x_{i}}=\ln w_{i}^{p}=\ln \left(g\left(x_{i}\right)\right)+v_{i}
$$

Taking a linear model for $g\left(x_{i}\right)$,

$$
\ln w_{i}^{p}=x_{i} \beta+v_{i}
$$

\footnotetext{
${ }^{5}$ The LIS data do not contain employer characteristics. Thus, such information is omitted from $x_{i}$. To the extent these omitted variables influence $u_{i}$, our worker incomplete information estimates may be biased. However, differences in these measures across countries are unaffected by this bias. These differences are akin to serially correlated errors in fixed-effects panel estimates being better than cross-sectional estimates. (See Bound and Krueger (1991).) Economy-wide institutional variables are included later in the analysis when comparing incomplete information across countries.
} 
where the dependent variable represents the individual's maximum potential wage offer; $x_{i}$ denotes a vector of individual characteristics defining the worker $i$ 's skill level; and $v_{i}$ is a disturbance distributed as $N\left(0, \sigma_{v}^{2}\right)$. With perfect information regarding what each firm pays, a worker would be able to locate the firm paying his or her maximum potential wage $w_{i}^{p}$. However, in a world of incomplete information, where search is costly, the typical worker defines a reservation wage $w_{i}^{R}$ below his or her potential wage. As indicated above, the offer wage one accepts $w_{i}^{0} \geq w_{i}^{R}$.

Combining (1) and (2), a worker's observed wage can be represented as:

$$
\ln w_{i}^{0}=\ln w_{i}^{p}-u_{i}
$$

where $u_{i} \geq 0$. This one-sided residual $u_{i}$ represents the extent incomplete information causes one to accept a wage lower than the market's potential wage. It reflects a monetary measure of incomplete information. Substituting (3) into (4) yields

$$
\ln w_{i}^{0}=x_{i} \beta+\varepsilon_{i}
$$

where $\varepsilon_{i}=v_{i}-u_{i}$. As already indicated $v_{i} \sim N\left(0, \sigma_{v}^{2}\right)$. We also assume that $u_{i} \sim N^{+}\left(\mu_{\mu_{i}}, \sigma_{\mu_{i}}^{2}\right)$, as is typical in frontier estimation. ${ }^{7}$

Based on the above assumptions, the composite error $(\varepsilon=v-u)$ must be rightward skewed for the approach to be valid. Therefore before proceeding, we test for skewness in $\varepsilon$. To do this, we follow Schmidt and Lin (1984) to obtain residuals from OLS regressions of (5) for each country and

\footnotetext{
${ }^{6}$ This is the measurement error omitted from past studies of incomplete information that simply use wage (or price) dispersion measures to get at incomplete information.

${ }^{7}$ It is not necessary to assume $u_{i} \sim N^{+}\left(\mu_{\mu_{i}}, \sigma_{\mu_{i}}^{2}\right)$. Other common distributions used in this context include the exponential, the Gamma, and lognormal. However, past studies found little qualitative difference between results using these different distributions. See Olson, Schmidt, and Waldman (1980) and Byeong-Ho Gong and Robin C. Sickles (1992).
} 
year. The specific test ${ }^{8}$ we adopt was developed by Royston (1991) and is a test for normality which combines two tests, one based on skewness and another based on kurtosis, into an overall test statistic. In no country or year do the test results supports the normality assumption (with p-value less than $0.1 \%$ ). Therefore, our hypothesis about the skewness of the residuals is strongly upheld justifying that we can proceed with estimation of (5) using frontier techniques to disentangle $u_{i}$ and $v_{i}$. To do this, we adopt the maximum likelihood approach to estimate (5) that incorporates a composed error term first proposed by Aigner, Lovell, and Schmidt (1977) and Meeusen and van den Broeck (1977). It assumes a non-negative one-sided error term, $u_{i}$, in addition to the traditional normally distributed error term, $v_{i}$. To understand the approach rewrite (5) as:

$$
w_{i}^{0}=g\left(x_{i}\right) \cdot \exp \left\{-u_{i}+v_{i}\right\}
$$

where $w_{i}^{0}$ is the actual observed earnings, as already defined, and $g\left(x_{i}\right)$ is the potential maximum earnings achievable barring random errors $v_{i}$. Actual earnings $\left(w_{i}^{0}\right)$ are less than potential maximum earnings $\left(g\left(x_{i}\right)\right)$ by the proportion $\left(1-\exp \left\{-u_{i}\right\}\right)$. In other words, $\left(1-\exp \left\{-u_{i}\right\}\right)$ is the effect of incomplete information.

As is standard in the literature we specify the $x_{i}$ vector to adhere to typical earnings functions. ${ }^{9}$ Based on current literature regarding functional form of earnings equations (Mincer, 1974, Heckman and Polachek, 1974, and Murphy and Welch, 1990), we express an individual's potential wage as

\footnotetext{
${ }^{8}$ The skewness and kurtosis test for normality (sktest) is described in the STATA reference manual, p. 226-228.

${ }^{9}$ As already noted, data on employers were not available, and hence omitted. However, in the latter cross-country analysis, the effect of these omitted variables are smaller, the more uniformly distributed these variables are across countries. Also, without data on tenure it is impossible to examine incomplete information differences between insider and outsider workers. However, were tenure data available one could compare information measures of recently hired workers to workers with longer tenure to ascertain the role on-the-job search of "insiders" within the firm. Preliminary evidence on this solely for the U.S. (Polachek-Yoon, 1987, Table 2) indicates that tenured employees have less incomplete information. Similarly were enough panel data available one could employ the techniques utilized by Polachek-Yoon (1997) to net out person-specific heterogeneity.
} 


$$
g\left(x_{i}\right)=\exp \left(\alpha_{0}+\alpha_{1} S_{i}+\alpha_{2} t_{i}+\alpha_{3} t_{i}^{2}+\alpha_{4} F_{i}\right)
$$

where,

$$
\begin{aligned}
& S_{i} \text { is the individual worker i's completed highest schooling level, } \\
& t_{i} \text { is the individual worker i's potential working experience, } \\
& t_{i}^{2} \text { is the quadratic term of i's experience level, and } \\
& F_{i} \text { is the individual worker i's gender dummy, } 1 \text { for female and } 0 \text { otherwise. }
\end{aligned}
$$

The above equation (7) gives a worker's potential wage in the absence of the incomplete information. In reality, because of the limits of finite search, a worker receives less than his or her potential maximum wage, and gets an observed wage $w_{i}^{o}$. To incorporate incomplete information, substitute (7) into (6) to obtain

$$
w_{i}^{o}=g\left(x_{i}\right) \cdot \exp \left\{-u_{i}+v_{i}\right\}=\exp \left(\alpha_{0}+\alpha_{1} S_{i}+\alpha_{2} t_{i}+\alpha_{3} t_{i}^{2}+\alpha_{4} F_{i}\right) \cdot \exp \left(-u_{i}+v_{i}\right)
$$

After taking the logarithm, it becomes:

$$
\ln w_{i}^{o}=\alpha_{0}+\alpha_{1} S_{i}+\alpha_{2} t_{i}+\alpha_{3} t_{i}^{2}+\alpha_{4} F_{i}-u_{i}+v_{i}
$$

The common approach is to estimate (9) using the (ln) likelihood function

$\ln L\left(w_{i}^{0} \mid \beta, \lambda, \sigma^{2}\right)=N \ln \frac{\sqrt{2}}{\sqrt{\Pi}}+N \ln \sigma^{-1}+\sum_{i=1}^{N} \ln \left[1-F\left(\varepsilon_{i} \lambda \sigma^{-1}\right)\right]-\frac{1}{2 \sigma^{2}} \sum_{i=1}^{N} \varepsilon_{i}^{2}$

proposed by Aigner et al. (1977) and Meeusen and van den Broeck (1977), where

$$
\begin{aligned}
& \sigma^{2}=\sigma_{u}^{2}+\sigma_{v}^{2} \\
& \lambda=\frac{\sigma_{u}}{\sigma_{v}}
\end{aligned}
$$


and where $\mathrm{f}$ and $\mathrm{F}$ are respectively the standard normal density and distribution functions. ${ }^{10}$ The expected value of the composite error is

$$
E(\varepsilon)=-E(u)=-\frac{\sqrt{2}}{\sqrt{\Pi}} \sigma_{u}
$$

the mean of the one-sided error term.

A problem with the above approach is it assumes $u_{i}$ to be unrelated to any of the independent variables. So, following Wang's (2002) strategy, we take account of how the independent variables can influence incomplete information by parameterizing $u_{i}$ to be a function of gender, marital status, race, schooling and experience, because each these variables affects a worker's opportunity costs of search. Thus, we assume

$$
\begin{aligned}
& u_{i} \sim N^{+}\left(\mu_{u i}, \sigma_{u i}^{2}\right) \\
& \mu_{u i}=\delta_{0}+\delta_{1} F_{i}+\delta_{2} M_{1 i}+\delta_{3} M_{2 i}+\delta_{4} R_{i}+\delta_{5} S_{i}+\delta_{6} t_{i} \\
& \sigma_{u i}^{2}=\exp \left\{\gamma_{0}+\gamma_{1} F_{i}+\gamma_{2} M_{1 i}+\gamma_{3} M_{2 i}+\gamma_{4} R_{i}+\gamma_{5} S_{i}+\gamma_{6} t_{i}\right\} \\
& v_{i} \sim N\left(0, \sigma_{v}^{2}\right)
\end{aligned}
$$

where

$u_{i}$ is truncated normally distributed with mean $\mu_{u i}$ and variance $\sigma_{u i}^{2}$,

$M_{1 i}$ is the individual worker i's marital status, 1 for married and 0 otherwise,

$M_{2 i}$ is the individual worker i's marital status, 1 for divorced, widowed, separated and 0 otherwise, and

$R_{i}$ is the individual worker i's race, 1 for white and 0 otherwise. (For countries other than U.S., 1 for the majority ethnic group and 0 otherwise).

${ }^{10}$ Note that based on Weinstein (1964), the likelihood function is based on the $\varepsilon_{i}$ distribution being

$$
f(\varepsilon)=\frac{2}{\sigma} f\left(\frac{\varepsilon}{\sigma}\right)\left[1-F\left(\varepsilon \lambda \sigma^{-1}\right)\right.
$$


The empirical estimate of the $u_{i}$ is obtained through its conditional expectation on the total error term $\varepsilon_{i}$, which is defined as

$$
\varepsilon_{i}=-u_{i}+v_{i}
$$

As noted by a referee, our choice of independent variables in (9), (13) and (14) is an important issue. Omitting key earnings determinants from (9) that are included in (13) and (14) can bias our estimates of incomplete information $(\mu)$. Take an example: Suppose education affects earnings positively. Then, including education in equation (9) implies lower potential earnings for the less educated, and higher potential earnings for the more educated. On the other hand, omitting education from equation (9) implies a single potential earnings measure for all. But given the frontier estimation adopted in likelihood function (10), potential earnings in this latter case are those of the most educated group. As a result, the gap between the potential wage and the actual wage is smaller for the more educated and larger for the less educated. Thus, incorporating education in (13) but not in (9) would imply a smaller $\mu$ for the most educated workers (hence less incomplete information) simply because the gap between the potential wage and the actual wage is smaller for the more educated when in reality frontier wages for the less educated should be lower than frontier wages for the more educated.

In this paper we adopt the Mincer earnings specification for (9). Here education, experience, and experience-squared identify potential earnings. In addition, we incorporate gender because gender is known to affect wage level. On the other hand, we include marital status and race in (13) and (14) but not (9) because marital status does not affect wage uniformly. For women marital status appears to lower earnings, whereas for men it appears to raise earnings. Similarly we incorporate race in (13) and (14) but not (9). The LIS data (which we describe later) includes majority ethnic group rather than race. For the U.S. this ethnicity variable denotes race, but not for the other countries. Blacks in the U.S. earn less than whites. However, there is no strong evidence outside the U.S. that minority ethnic groups earn less than the majority ethnicity groups. Thus we hesitate to include this ethnicity variable in the wage equation. As for the incomplete information equation, marriage and race are included because married, widowed/divorced, and majority ethnicity groups are assumed to have different search behaviors. We expect these groups to search more not only because their marginal gains for an additional search are higher, but also because their search costs are lower. The determinants of search do not always perfectly match those of earning patterns and therefore, the variables in the two equations are not required to be the same.

We admit some biases can creep in because of difficulty in specifying the variables that affect $\mu$ but not w, and vice versa. Mostly for this reason, later in the paper, we adopt an additional approach to identify country institutional factors that affect $\mu$. In this latter approach (comparable to differences-in-differences) the above type errors cancel out as long as they are uniform across countries. 
Maximum likelihood is used to estimate equation (17), given assumptions (12) to (16). ${ }^{11}$ The $\log$ likelihood function for a sample of $\mathrm{N}$ workers is

$\ln L\left(w_{i}^{0} \mid \beta, \lambda, \sigma\right)=C-\sum_{i} \ln \sigma_{i}-\sum_{i} \ln \Phi\left(\frac{\mu_{u i}}{\sigma_{u i}}\right)+\sum_{i} \ln \Phi\left(\frac{\mu_{u i}}{\sigma_{i} \lambda_{i}}-\frac{\varepsilon_{i} \lambda_{i}}{\sigma_{i}}\right)-\frac{1}{2} \sum_{i}\left(\frac{\varepsilon_{i}+\mu_{u i}}{\sigma_{i}}\right)^{2}$

where

$$
\begin{aligned}
& \sigma_{i}=\left(\sigma_{u i}^{2}+\sigma_{v}^{2}\right)^{1 / 2} \\
& \lambda_{i}=\sigma_{u i} / \sigma_{v}
\end{aligned}
$$

As discussed above, we use $1-E\left(\exp \left\{-u_{i}\right\} \mid \varepsilon_{i}\right)$ as a measure of a worker's incomplete information. The advantage of this measure is that it is bounded by $(0,1)$, which is easily interpreted as the proportion of the potential maximum wage a worker gives up due to the incomplete information. So the bigger the 1- $E\left(\exp \left\{-u_{i}\right\} \mid \varepsilon_{i}\right)$, the more incomplete one's knowledge of available wages. The formula to obtain each worker's incomplete information is

$$
1-E\left(\exp \left\{-u_{i}\right\} \mid \varepsilon_{i}\right)=1-\frac{1-\Phi\left[\sigma_{*_{i}}-\left(\tilde{\mu}_{i} / \sigma_{*_{i}}\right)\right]}{1-\Phi\left[\left(-\tilde{\mu}_{i}\right) / \sigma_{*_{i}}\right]} \cdot \exp \left\{\left(-\tilde{\mu}_{i}\right)+\frac{1}{2} \sigma_{*_{i}}^{2}\right\}
$$

where

$$
\begin{aligned}
& \sigma_{*_{i}}^{2}=\sigma_{u i}^{2} \sigma_{v}^{2} / \sigma_{i}^{2} \\
& \tilde{\mu}_{i}=\left(-\sigma_{u i}^{2} \varepsilon_{i}+\mu_{u i} \sigma_{v}^{2}\right) / \sigma_{i}^{2}
\end{aligned}
$$

The estimate of incomplete information is the average of all workers' incomplete information. So each country year's incomplete information is

$$
\mu_{j}=\frac{1}{N_{j}} \sum_{i=1}^{N_{j}}\left[1-E\left(\exp \left\{-u_{i}\right\} \mid \varepsilon_{i}\right)\right]
$$

where $N_{j}$ is the total number of workers for country year $\mathrm{j}$.

\section{The Data}

\footnotetext{
${ }^{11}$ See Stevenson (1980).
} 
Our first task is to compute each worker's incomplete information defined in equation (20), using the maximum likelihood estimation formulated in equation (17). In the LIS data, there are three data files for each country and year. We use the personal file, which has information on work status, personal income, education as well as other basic individual characteristics. For each of the 29 countries, the number of available years differs, ranging from one year for Estonia to nine years for Canada and the United States. For two reasons, we use only part of the available countries for the analysis. First, our final goal is to understand how institutional differences explain variations in incomplete information across countries. However, crucial variables to test hypotheses related to institutional perspectives are not available for all LIS countries and years. Generally LIS has sufficient data for many, but not all OECD countries. So for this reason we first restrict our analysis to the OECD countries and years, which contain the full complement of demographic information that we need for analysis. (We also include Israel - our only non-OECD country - because LIS contains the relevant information, and because this paper was also presented in Israel.) Second, we only include countries and years for which the nonlinear maximum likelihood estimation of equation (17) converged. Of the 23 potential OECD countries (and Israel), this left 11 countries for which we have sufficient data. They are the United States, Canada, the United Kingdom, Germany, Sweden, Finland, Ireland, Norway, Netherlands, Czech Republic and finally Israel. They span North America and all parts of Europe.

\section{Within Country Regression Results}

Summary statistics are provided in Table 1. For most countries and years, the average schooling is around 11 to 12 years, and the average potential experience is between 20 and 25 years. So, across these OECD countries, most workers have relatively comparable educational backgrounds, and are similar in age. Also, female workers constitute about half of the population interviewed. (Though, not shown in the table, a greater proportion of women did not work for pay.) The ethnicity variable depicts the proportion of the population constituting a country's majority racial or ethnic group. In the US, this is the proportion white. Married workers are around $60 \%$ of the population, and divorced or widowed workers are in the 5-20\% range. Mean wages are contained in the last column, and are defined either as hourly wages or annual earnings, depending on the available data. We expect more variation in annual earnings because hourly wages fluctuate less as work hours vary. In the statistical analysis to follow, we add a dummy categorical variable to signify country-years with hourly wage data.

Table 2 contains the regression results of equation (9). Columns (1) and (2) give the country and year; columns (3) through (6) give the coefficient values for schooling, potential experience, potential experience-squared, and gender; and finally column (7) gives estimates of the extent of incomplete information obtained from equation (23). We begin by explaining Columns (3) through (6) since they reflect earnings function parameters typically obtained when estimating Mincer earnings functions.

The schooling variable coefficient depicts the average rate of return for an additional year of school. For more than half of the countries, this rate of return is increasing over time. (Only a few counties 
have decreasing rates of return.) This pattern is consistent with other data sets as well as with technological change. It implies that the more educated absorb advanced technology easily, and that their rate of pay per year of schooling is increasing secularly. ${ }^{12}$ The experience coefficients yield concave earning profiles, shown by the consistently negative squared-term. The female dummy variable is uniformly negative, suggesting that in all the countries (that we consider), women earn less than men, given adjustments for schooling and experience. Overall, these earnings function parameters are typical of those found in the literature.

Estimates of incomplete information, based on equation (23), are given in Column 7. They range from 0.16 to 0.58 , but average about 0.3 . This means that incomplete information causes the average worker to get about $30 \%$ less than his or her potential. An examination of the values indicates strong consistency within countries, since these values differ more country-to-country than within countries. Within countries incomplete information measures do not reveal any apparent time pattern. Incomplete information seems to be increasing in Sweden, Czechoslovakia, Finland, Germany, Netherlands and Israel, while in Norway it is decreasing. On the other hand, time trends are relatively flat for the United States, the United Kingdom, Canada and Ireland. Usually technological improvements mirror time trends. The lack of a time trend might suggest that technological improvements are not necessarily associated with decreasing incomplete information, as common sense might have implied. ${ }^{13}$

What factors affect the level and distribution of incomplete information within each country? To answer this question, we adopt Wang's (2002) method to compute marginal effects of $\mu_{u i}$ 's covariates listed in equation (13) (Table 3) and $\sigma_{u i}^{2}$ 's covariates given in equation (14) (Table 4). ${ }^{14}$ Beginning with Table 3, we see a number of trends. For example, the mostly negative marginal effects of school indicate that additional schooling reduces a worker's incomplete information. This finding is consistent with Stephenson's (1976) argument that workers with more education gather more wage information by searching more efficiently. Similarly, about three-quarters of the cases show married workers, and two-thirds of the cases show that widowed and divorced workers, have more information than singles. This result is consistent with higher married and widowed labor

\footnotetext{
${ }^{12}$ As schooling levels rise, the wage distribution becomes wider. Although a wider earnings distribution increases search gains, it need not imply more information since search costs also rise. Perhaps this is the reason we see no time trends regarding incomplete information.

13 Whereas technological improvement provides the opportunity for more search, the whole search process can become more overwhelming, making the job choice decision more complicated. For instance, by intensively searching through the internet, individuals decrease search costs. These decreased search costs might imply more search but less real information if, for example, wages are not posted. Thus technology could leave workers with less real information.

${ }^{14}$ For the details, see equation (9) and equation (10) in Wang's paper.
} 
force participation rates (Taubman, 1976), which leads to larger marginal gains from search.

Further, as hypothesized (McCall, 1973) blacks exhibit lower labor force participation and possibly higher search costs, so they might acquire less information than whites. In our international data, we show that on average minority ethnic groups have less complete information than majority groups, which is an extension of McCall's argument. Also, from Table 3, potential experience reduces workers' incomplete information in over $80 \%$ of the observations. Finally, incomplete information is larger among female workers than male workers, again consistent with less lifetime female labor force participation.

Another observation regarding these marginal effects in Table 3 is that the patterns are more consistent within a specific country, than across countries. As such, any covariate's marginal effect is likely to have a uniform sign within a particular country, but not necessarily across countries. This uniformity within countries underscores the importance of using cross-country institutional differences to explain how incomplete information differs from country-to-country.

Recall from equation (5) that $\sigma_{u i}^{2}$ depicts the dispersion of incomplete information. How individual characteristics affect this dispersion is parameterized in equation (15). The impacts of these characteristics on $\sigma_{u i}^{2}$ are given in Table 4. They indicate the degree incomplete information fluctuates across socioeconomic groups. As an example, take race. From Table 3, incomplete information is smaller for whites than for blacks. But, the negative ethnicity coefficient in Table 4 implies that whites exhibit smaller dispersion in incomplete information than blacks. This implies a relatively wider range in incomplete information for blacks than whites. Thus the variance of incomplete information is greater for blacks than whites. Similarly, though on average females garner less information in total, they exhibit greater variance in the amount of information they gather, as well. For the most part being older (having more potential experience) reduces this dispersion, as does being married or widowed, and as does having more education (except for the United Kingdom, Germany, The Netherlands and Israel).

\section{Why Incomplete Information Differs Across Countries? An Examination of Institutional Factors}

So far we have estimated incomplete information and examined how it varies within countries. We have seen that an employee's characteristics, especially those characteristics affecting one's incentive to search, influence the amount of wage related information one acquires. However, a country's institutions may also be important, but identifying the impact of these institutions is difficult to discern with a limited number of cross-sections for a given country. For this reason, we now do a comparative analysis by contrasting institutional differences across each of the eleven countries to explain inter-country differences in incomplete information. 


\section{UI and Incomplete Information}

Perhaps unemployment insurance (UI) is the most studied institution regarding information and search. Ehrenberg and Oaxaca (1976), Jurajda and Tannery (2003), and numerous other studies find that UI increases unemployment duration, job search and post-unemployment wage. Hofler-Polachek (1985), Polachek-Yoon (1987) and Hofler-Murphy (1992) corroborate this result using one of the frontier estimation techniques described above. They find that having received UI leads to less incomplete information. As already mentioned, this finding is consistent with search theory explanations that UI subsidizes search costs leading to longer search, better wages, and more information (less incomplete information). Whereas these studies test this proposition with U.S. data, to the best of our knowledge, none examine other countries; nor do any do comparative analysis across countries. In what follows, we perform a comparative analysis using the eleven countries mentioned above. We test whether variations in UI are related to worker incomplete information.

To achieve this goal, we need UI information for these countries. One measure, found in the "OECD Employment Outlook," is a country's public expenditure as a percentage of GDP. The advantage of this measurement is that we have each country's actual expenditures on UI, instead of some nominal benefit measure that might not be implemented exactly for each worker. The disadvantage is that this measure might reflect a country's business cycle rather than how it subsides an individual's search. Because UI (as a proportion of GDP) is narrowly distributed (most of the UI expenditures are less than 2 percent of countries' GDP, with a few over 3 percent), we convert the UI variable to a logarithm. This assumption is consistent with UI's impact being nonlinear. A logarithmic specification implies a larger impact when UI is initially small, which is what we expect.

\section{Other Institutional Factors}

Besides UI, we examine several other institutional factors that might contribute to the explanation of workers' incomplete information. These variables are population density, proportion of employment in industry, rural population and the inflow of foreign workers. Information on each of these is obtained from World Bank data.

The first three variables get at how information is concentrated among the population. As such they reflect the costs of search, since we presume that search costs rise when information is dispersed more widely and harder to find. So for example, a more dense population implies quicker access to information networks. Also, a more dense population probably means that jobs are closer in proximity. A large rural population implies the opposite, namely sparse harder to find information, with jobs spread over wider distances. Sandell (1980) suggests that geographically concentrated opportunities lowers search costs, which prolongs search, and reduces incomplete information. In contrast to urban areas, rural regions are less concentrated with job opportunities, and therefore likely result in more incomplete information.

Unionization rates rise as a country's industrial employment increases (Polachek, 2004). Also 
unions provide information to employers and employees regarding wages and jobs (Polachek and Yoon, 1987) and unions compress wage distributions (Freeman, 1980). Thus because industrialized countries are more unionized, we expect workers in more industrial countries to be more informed and have less incomplete information.

Finally, we examine the inflow of foreign workers. A considerable body of research examines the relative success of immigrants. For example, past studies of U.S. immigration note that wages of newly arrived immigrants lag behind native wages (Chiswick, 1978), but that the assimilation process can cause earnings of the foreign born to eventually overtake U.S. natives (Chiswick, 1986), though there remains some debate on the issue (Borjas, 1985). In any case, the whole assimilation process involves increased acquisition of information on domestic labor markets, and the use of this information in the search process (Daneshvary, et al., 1992). Further, new lower-waged foreign workers, who come to a country with less initial knowledge of wage structures can affect the overall distribution of wages. Since generally, having less information implies that immigrant workers receive lower wages than natives, wage dispersion increases, as does skewness. Thus the effect of foreign workers is likely to be a more left-skewed earnings distribution, resulting from incomplete information (holding skills constant). But this result is not always found. A study of German immigrants, using data from 2000, finds natives and immigrants at about the same distance from the frontier (Lang, 2004). For this reason, the effect of foreign in-migration on incomplete information is still an open question.

Table 5 gives a detailed summary of these variables. Column (1) contains the variable name and definition. Column (2) contains the number of country-year cells for which data are available. Columns (3) - (6) contain summary statistics. Rows (1) through (7) contain statistics for each of the institutional variables just mentioned. Generally data are available for most of the time periods and countries. The exceptions are for UI (which is missing eight of 45 observations) and foreign worker inflows (which is missing 24 observations). This latter restriction necessitates running separate analysis of foreign worker inflow effects. Row (8) gives estimates of the incomplete information variable (obtained from Table 2). Because the effects of incomplete information are affected by using annual instead of hourly wages, we normalize those 18 observations that were based on annual instead of hourly wages. This normalization unifies the incomplete information measurement to make it consistent across counties so that inter-country comparisons can be made. These values are given in row (10). ${ }^{15}$

\section{Cross-country Analysis}

Cross-country regression results are given in Table 6. Country (and year) specific incomplete information measures derived from (23) are the dependent variables, and the country-specific institutional variables just described serve as independent variables. We present five models that explain incomplete information as a function of these institutional factors. Model (1)

\footnotetext{
${ }^{15}$ We adjust the 18 incomplete information estimates by the hourly wage dummy coefficient in a regression of incomplete information on the hourly wage dummy variable.
} 
concentrates on UI. Model (2) concentrates on the population density and industrial structure variables. Models (3) and (4) concentrate on the inflow of foreign workers. Finally, Model (5) integrates most of the institutional factors into one model. ${ }^{16}$ We present four parameters for each independent variable. The first is the simple OLS coefficient. The second is the t-statistic based on the robust standard error. The third is the marginal effect caused by a one standard deviation change in the independent variable. Finally the fourth is an elasticity measure describing the percent change in incomplete information caused by a one percent change in the independent institutional characteristic. To distinguish between incomplete information variables derived from annual versus incomplete information measures derived from hourly wage data, we adjust for hours of work. ${ }^{17}$

The first model focuses on how UI impacts incomplete information. A one-unit increase in the logarithm of a country's UI expenditures (relative to GDP) reduces incomplete information by .05 . This means that a one extra logarithm unit of UI spending (relative to GDP) induces workers to get $5 \%$ closer to their maximum attainable wage. The -.036 coefficient implies that a one standard deviation increase in a country's logarithm of UI (relative to GDP) causes workers to get $3.6 \%$ closer to their potential wage. Finally the -.048 elasticity measure indicates that a doubling of the logarithm of UI spending (from its mean value) leads to 4.8 percentage decrease in worker incomplete information (from its mean value). Most important, these coefficients substantiate search theory. Increasing UI reduces search costs. Lower search costs increase search leading to more worker information on the wage structure.

The second model focuses on population density, rural population, and industrial employment. If, as we postulate, each of these influences search costs, then we should expect these variables to have an effect on worker incomplete information. Indeed, this is precisely what we find. Both a more dense population and a high level of industrial employment provide information networks, and thus decrease incomplete information. A large rural population increases distances, thereby increasing information costs. This leads to decreases in employee information, and hence a greater level of employee incomplete information.

The marginal effect of a one standard deviation change in each of these three variables is very similar in magnitude (0.03). This means that a one standard deviation increase in either population density or industrial employment decreases a country's incomplete information by about $10 \%{ }^{18}$ Analogously, one could look at this another way: Incomplete information of about 0.30 (the mean reported in Table 5) implies that employees on average earn about $70 \%$ of their maximum possible wage. A one standard deviation increase in population density raises

\footnotetext{
${ }^{16}$ Foreign worker inflows cannot be integrated because the limited number of observations on this variable precludes sufficient degrees of freedom. In addition, we eliminated the industrial employment variable because it becomes insignificant.

${ }^{17}$ This adjustment is omitted from Models (3) and (4) because each of the 21 observations contains incomplete information measures derived solely from hourly wage data.

${ }^{18}$ According to Table 5, average adjusted employee incomplete information is about 0.30 . A 0.03 change is about $10 \%$.
} 
employee information (lowers employee incomplete information) by about $10 \%$. Thus workers in (a one standard deviation) denser area get wages $3 \%$ closer to their maximum. Though this analysis is performed across countries, it is well known that urban areas pay higher wages, and often for unexplainable reasons. Perhaps one reason is that better information networks lead to less employee incomplete information. ${ }^{19}$

Models (3) and (4) incorporate the inflow of foreign workers. Both these models show that a growing foreign workforce decreases worker information. A standard deviation increase in inflow of foreign workers yields a $3.7 \%$ wage loss in model (3) and a $2.4 \%$ loss in model (4). The elasticity measurements for these two models are .049 and .116 respectively. Thus doubling the inflow of foreign workers induces a $4.9 \%$ increase in incomplete information in model (3), and a $11.6 \%$ increase in model (4). ${ }^{20}$ Thus, despite major contributions foreign workers probably contribute to a host country's economic development, they also affect the wage distribution, which becomes more skewed to the left. As such, the average worker receives a wage proportionally lower than the maximum available wage. These lower wages are consistent with an increase in incomplete information.

Combining all variables (Model (5)) does not alter the results. ${ }^{21}$ Again, UI is associated with significantly increased worker wages, relative to potential wages. This is consistent with increased worker information. Also, a more dispersed population is associated with wages being lower relative to potential wages. In contrast with UI, this is consistent with less employee information.

From a policy perspective, these results show that a country can reduce its incomplete information through governmental efforts, such as spending more on UI. Also, from a policy perspective, the results are consistent with information dissemination being linked to economic development. As a country develops, its geographical structure often changes, so that rural (relative to urban) population is reduced. From the above coefficients, relative rural population reductions are associated with more worker information.

In making these claims, it is important to note that information rises because the overall wage

\footnotetext{
${ }^{19}$ The large industrial employment and rural population elasticities (Table 6) at first surprised us. However, an examination of the means (or median for population density) and standard deviations of these variables reveals values respectively five-times the size and twice the size of their standard deviations. So these two elasticity measures are really very consistent with the marginal effects.

${ }^{20}$ More specifically, a doubling of foreign workers (i.e., a new inflow of 77,700 foreign workers for a country already with 77,700 (median value from Table 5) foreign workers and incomplete information of 0.359 ) will increase incomplete information by .018 units, which is $4.9 \%$ of .359. Similarly, increasing the proportion of foreign workers from $0.161 \%$ to $0.322 \%$ yields an increase in incomplete information by 0.142 , which is $11.6 \%$ of 0.359 .

${ }^{21}$ As noted in footnote \#13, an insufficient number of observations precludes including the foreign worker inflow. The industrial employment variable has the correct sign, is statistically insignificant. Thus we also eliminate this variable in Model (5).
} 
distribution becomes more left-skewed, not because wages simply rise equally across the whole distribution. Thus, we are not making a trivial statement regarding development and wage levels. While it is very well known that economic development raises a society's wages, a rising overall wage does not constitute increasing information. By our original definition, incomplete information is based on changes in wage distribution skewness, and not on the distribution's overall mean wage level. Thus our proclaimed result goes beyond traditional development economics.

\section{A Graphical Depiction}

To get another view of the above results, we graph incomplete information against each of these explanatory variables (Figure 1 through Figure 6). Every observation is labeled by country name. Also, the graphs contain a fitted line mirroring each of the above model's predictions.

As easily seen, the cross-country predictions blatantly stand out. Nations with greater UI benefits (Figure 1) have less incomplete information (more employee information). Workers in more densely populated nations have less incomplete information (Figure 2). Nations with greater rural populations have more incomplete worker information (Figure 3). Industrialized nations have less incomplete information (Figure 4). Finally, nations with a greater influx of foreign workers have more incomplete information (Figures 5 and 6).

One interesting observation is noted from these graphs. Within-country results are not always as strong as the between country results. Take incomplete information versus the logarithm of UI (Figure 1). Whereas greater UI decreases incomplete information in the US, Canada, the UK, Israel, the Netherlands, Ireland and Sweden, it does not in Norway, Finland and Germany. ${ }^{22}$ Rather, these latter within-country patterns seem to indicate rising incomplete information as UI increases. These few counter examples imply that UI alone does not explain all changes of the within country incomplete information. Perhaps UI must be examined in conjunction with welfare policies, given the preponderance of Scandinavian countries among this latter group.

Probably because a country's population density and rural population change very slowly over short time periods, we observe similarly anomalous results for within-country comparisons in Figure 2 and Figure 3. As a result, we observe almost no within-country relationship in these Figures, even though the between country relation is significant.

On the other hand, the within country observations follow the cross-country trends in Figures 4, 5 and 6. Incomplete information decreases within a country when its industrial employment increases (Figure 4). Incomplete information tends to rise with inflows of foreign workers (Figures 5 and 6).

\footnotetext{
${ }^{22}$ Missing UI data preclude plotting Czechoslovakia in the Firgure.
} 


\section{Conclusion}

In this paper, we define a tractable procedure to measure incomplete information in the labor market. The procedure is based on econometric frontier estimation techniques, and is consistent with search theory. It is an improvement over past measures because it holds individual characteristics constant and nets out random effects.

We apply the technique to eleven countries over various years. We find incomplete information leads workers to receive on average about $30-35 \%$ less pay than they otherwise would have earned, had they information on what each firm paid. Generally married men and women suffer less from incomplete information than the widowed or divorced, and singles suffer the most. Women suffer more than men do. Schooling and labor market experience reduce these losses. But institutions within a country matter, as well. For example, we find that workers in countries that strongly support unemployment insurance (UI) receive wages closer to their potential. Doubling UI decreases incomplete information and results in 5\% higher wages. A more dense population reduces search costs leading to less incomplete information and higher wages. A more industrial economy disseminates wage information better, so that workers exhibit less incomplete information. Finally, we examined the effect of foreign worker inflows on incomplete information. Data within countries, as well as data from a cross-country comparison, yield comparable results. Foreign worker inflows skew wages to the left. In the short-run they increase incomplete information, and at the same time they reduce average wage levels.

In reaching these conclusions it is important to note that we achieve our estimates of incomplete information based on the skewness of the wage distribution and not on wage levels. Thus, whereas we find that individual characteristics such as race, gender and work experience lead to higher wage levels in their own rite (i.e., these variables have a direct effect), they also do so through their effects on incomplete information. Similarly whereas we find that a country's institutional characteristics such as commitment to UI, sanctions against foreign workers, or a more developed industrial structure directly raise wages, these country characteristics also do so through their effects on incomplete information. These latter effects of incomplete information on wage level are obtained from wage distribution skewness, and not from symmetric movements in the entire wage distribution. 
Table 1: Mean of the Variables from the Individual Country-Year Regressions**

\begin{tabular}{|c|c|c|c|c|c|c|c|c|c|}
\hline Country & Year & School & $\begin{array}{r}\text { Potential } \\
\text { Experience }\end{array}$ & Female & $\begin{array}{l}\text { Majority } \\
\text { Ethnicity }\end{array}$ & Married & $\begin{array}{l}\text { Divorced } \\
\text { Widowed }\end{array}$ & Wage & $\begin{array}{l}\text { Sample } \\
\text { Size }\end{array}$ \\
\hline $\mathrm{CN}^{*}$ & 1981 & 11.117 & 21.813 & 0.172 & & & & 10.452 & 9063 \\
\hline $\mathrm{CN}^{*}$ & 1987 & 10.822 & 24.353 & 0.519 & & 0.618 & 0.124 & 12.131 & 11976 \\
\hline $\mathrm{CN}^{*}$ & 1991 & 11.646 & 25.152 & 0.517 & & 0.636 & 0.126 & 15.110 & 20514 \\
\hline $\mathrm{CN}^{*}$ & 1994 & 11.984 & 25.164 & 0.521 & & 0.619 & 0.135 & 16.020 & 39635 \\
\hline $\mathrm{CN}^{*}$ & 1997 & 12.066 & 26.507 & 0.513 & & 0.646 & 0.130 & 14.716 & 33052 \\
\hline $\mathrm{CN}^{*}$ & 1998 & 12.492 & 25.488 & 0.513 & & 0.487 & 0.229 & 15.256 & 36566 \\
\hline $\mathrm{CN}^{*}$ & 2000 & 13.288 & 18.450 & 0.487 & & 0.529 & 0.201 & 16.080 & 32548 \\
\hline $\mathrm{CZ}$ & 1992 & 11.804 & 20.900 & 0.471 & & 0.733 & 0.103 & 518.575 & 18910 \\
\hline $\mathrm{CZ}$ & 1996 & 10.413 & 23.784 & 0.466 & 0.992 & 0.694 & 0.108 & 1140.721 & 31435 \\
\hline FI & 1987 & 9.351 & 22.222 & 0.474 & 0.933 & 0.614 & 0.073 & 63344.97 & 18793 \\
\hline FI & 1991 & 9.706 & 22.374 & 0.486 & 0.939 & 0.629 & & 85465.26 & 17444 \\
\hline FI & 1995 & 11.145 & 21.195 & 0.493 & 0.948 & 0.586 & 0.106 & 88175.4 & 12822 \\
\hline FI & 2000 & 11.693 & 22.208 & 0.491 & 0.942 & 0.584 & 0.082 & 112289.7 & 14137 \\
\hline GE* & 1984 & 7.638 & 29.046 & 0.511 & 0.821 & 0.638 & 0.125 & 19.146 & 4844 \\
\hline GE* & 1989 & 8.483 & 28.992 & 0.504 & 0.804 & 0.634 & 0.132 & 25.493 & 3914 \\
\hline GE* & 1994 & 8.780 & 29.558 & 0.519 & 0.813 & 0.649 & 0.135 & 34.482 & 5849 \\
\hline GE* & 2000 & 12.607 & 27.399 & 0.516 & 0.937 & 0.629 & 0.196 & 24.574 & 5537 \\
\hline IE* & 1994 & 9.481 & 29.716 & 0.500 & 0.997 & 0.628 & 0.105 & 5.035 & 2762 \\
\hline IE* & 1995 & 9.471 & 30.007 & 0.501 & 0.993 & 0.621 & 0.108 & 5.217 & 2396 \\
\hline IE* & 1996 & 9.492 & 29.905 & 0.495 & 0.995 & 0.611 & 0.116 & 5.239 & 2327 \\
\hline IS & 1992 & 12.531 & 19.813 & 0.452 & 0.473 & 0.755 & 0.058 & 38082.47 & 5429 \\
\hline IS & 1997 & 12.019 & 22.691 & 0.514 & 0.431 & 0.602 & 0.108 & 64932.53 & 5817 \\
\hline $\mathrm{NL}^{*}$ & 1983 & 9.881 & 22.597 & 0.102 & & 0.793 & 0.053 & 21.685 & 2162 \\
\hline NL & 1987 & 9.417 & 20.573 & 0.361 & & 0.677 & 0.046 & 41329.14 & 3054 \\
\hline NL & 1991 & 11.615 & 17.760 & 0.396 & & 0.64 & 0.048 & 40200.91 & 3828 \\
\hline NL* & 1994 & 10.868 & 26.795 & 0.526 & & 0.648 & 0.113 & 26.229 & 4707 \\
\hline $\mathrm{NL}^{*}$ & 1999 & 12.693 & 19.441 & 0.463 & & 0.612 & 0.071 & 29.216 & 5110 \\
\hline NW & 1991 & 11.485 & 19.930 & 0.470 & & 0.554 & 0.061 & 115304.8 & 12786 \\
\hline NW & 1995 & 11.804 & 21.152 & 0.479 & & 0.571 & 0.074 & 150085.6 & 13538 \\
\hline NW & 2000 & 12.734 & 20.755 & 0.486 & 0.939 & 0.551 & 0.082 & 209902.6 & 19214 \\
\hline SW & 1992 & 11.144 & 25.180 & 0.492 & 0.965 & 0.802 & & 145644.9 & 15623 \\
\hline SW & 1995 & 10.740 & 24.248 & 0.495 & 0.973 & 0.765 & & 157548.8 & 16828 \\
\hline SW & 2000 & 12.207 & 22.140 & 0.491 & 0.961 & 0.501 & 0.084 & 189576 & 17235 \\
\hline UK & 1986 & 10.482 & 21.153 & 0.429 & & & & 8121.4 & 6251 \\
\hline $\mathrm{UK}^{*}$ & 1991 & 10.744 & 21.295 & 0.478 & & 0.659 & 0.140 & 6.277 & 6398 \\
\hline $\mathrm{UK}^{*}$ & 1994 & 10.283 & 31.504 & 0.528 & & 0.615 & 0.225 & 7.295 & 21659 \\
\hline UK* & 1995 & 11.094 & 22.043 & 0.504 & & 0.649 & 0.180 & 7.474 & 5472 \\
\hline US & 1969 & 11.491 & 20.311 & 0.421 & 0.885 & 0.658 & 0.099 & 5566.403 & 15715 \\
\hline US* & 1974 & 11.327 & 23.539 & 0.535 & 0.815 & 0.610 & 0.151 & 4.650 & 12087 \\
\hline US* & 1979 & 12.804 & 20.336 & 0.472 & & & & 6.703 & 15470 \\
\hline US* & 1986 & 12.227 & 23.362 & 0.535 & 0.785 & 0.554 & 0.175 & 9.737 & 13048 \\
\hline US* & 1991 & 12.429 & 24.408 & 0.532 & 0.745 & 0.540 & 0.195 & 10.467 & 19636 \\
\hline US* & 1994 & 12.598 & 24.130 & 0.531 & 0.733 & 0.517 & 0.203 & 11.962 & 79323 \\
\hline US* & 1997 & 12.675 & 25.060 & 0.532 & 0.719 & 0.549 & 0.194 & 13.795 & 64369 \\
\hline US* & 2000 & 12.818 & 25.219 & 0.521 & 0.701 & 0.581 & 0.158 & 15.320 & 63890 \\
\hline
\end{tabular}

Data Source: Luxembourg Income Study

* Denotes countries with hourly wage, otherwise with annual wage data are given.

**The mean is based on those in the population with positive wages (earnings). Missing variables are denoted as blanks, Variable definitions:

School is average years of schooling;

Potential Experience is average years of working experience, calculated by age-school-6;

Female is a gender dummy, 1 for female and 0 otherwise;

Majority Ethnicity is ethnicity dummy, 1 for majority ethnic group and 0 otherwise;

Married is marital status dummy, 1 for married and 0 otherwise;

Divorced/Widowed is a marital status dummy, 1 for divorced/widowed and 0 otherwise;

Wage is average wage, either specified as hourly wage or annual earnings. 
Table 2: Within Country Regression Results

\begin{tabular}{|c|c|c|c|c|c|c|}
\hline Country & Year & School & $\begin{array}{c}\text { Potential } \\
\text { Experience }\end{array}$ & $\begin{array}{c}\text { Experience } \\
\text { Square }\end{array}$ & Female & $\begin{array}{l}\text { Incomplete } \\
\text { Information }\end{array}$ \\
\hline $\mathrm{CN}^{*}$ & 1981 & 0.050 & 0.024 & -0.0003 & -0.276 & 0.281 \\
\hline $\mathrm{CN}^{*}$ & 1987 & 0.066 & 0.031 & -0.0004 & -0.205 & 0.377 \\
\hline $\mathrm{CN}^{*}$ & 1991 & 0.067 & 0.021 & -0.0002 & -0.211 & 0.347 \\
\hline $\mathrm{CN}^{*}$ & 1994 & 0.070 & 0.024 & -0.0002 & -0.202 & 0.348 \\
\hline $\mathrm{CN}^{*}$ & 1997 & 0.080 & 0.024 & -0.0002 & -0.204 & 0.347 \\
\hline $\mathrm{CN}^{*}$ & 1998 & 0.103 & 0.036 & -0.0004 & -0.322 & 0.251 \\
\hline $\mathrm{CN}^{*}$ & 2000 & 0.098 & -0.006 & 0.0002 & -0.314 & 0.340 \\
\hline $\mathrm{CZ}$ & 1992 & 0.077 & 0.023 & -0.0004 & -0.324 & 0.259 \\
\hline $\mathrm{CZ}$ & 1996 & 0.093 & 0.020 & -0.0003 & -0.321 & 0.274 \\
\hline FI & 1987 & 0.082 & 0.066 & -0.0009 & -0.413 & 0.535 \\
\hline FI & 1991 & 0.083 & 0.056 & -0.0007 & -0.383 & 0.536 \\
\hline FI & 1995 & 0.067 & 0.043 & -0.0005 & -0.381 & 0.563 \\
\hline FI & 2000 & 0.065 & 0.043 & -0.0005 & -0.421 & 0.563 \\
\hline GE* & 1984 & 0.089 & 0.030 & -0.0004 & -0.243 & 0.252 \\
\hline GE* & 1989 & 0.073 & 0.021 & -0.0002 & -0.169 & 0.267 \\
\hline GE* & 1994 & 0.067 & 0.013 & $-.0001 * *$ & -0.151 & 0.281 \\
\hline $\mathrm{GE}^{*}$ & 2000 & 0.105 & 0.020 & -0.0002 & -0.187 & 0.357 \\
\hline $\mathrm{IE}^{*}$ & 1994 & 0.098 & 0.041 & -0.0004 & -0.116 & 0.324 \\
\hline $\mathrm{IE}^{*}$ & 1995 & 0.087 & 0.038 & -0.0004 & -0.128 & 0.312 \\
\hline $\mathrm{IE}^{*}$ & 1996 & 0.091 & 0.038 & -0.0004 & -0.110 & 0.353 \\
\hline IS & 1992 & 0.105 & 0.048 & -0.0006 & -0.486 & 0.320 \\
\hline IS & 1997 & 0.128 & 0.042 & -0.0005 & -0.514 & 0.341 \\
\hline NL* & 1983 & 0.083 & 0.048 & -0.0006 & -0.081 & 0.156 \\
\hline NL & 1987 & 0.084 & 0.061 & -0.0008 & -0.172 & 0.256 \\
\hline NL & 1991 & 0.064 & 0.038 & -0.0005 & -0.239 & 0.398 \\
\hline NL* & 1994 & 0.060 & 0.025 & -0.0002 & -0.046 & 0.275 \\
\hline NL* & 1999 & 0.065 & 0.026 & -0.0003 & -0.058 & 0.297 \\
\hline NW & 1991 & 0.074 & 0.042 & -0.0007 & -0.416 & 0.581 \\
\hline NW & 1995 & 0.069 & 0.046 & -0.0007 & -0.436 & 0.527 \\
\hline NW & 2000 & 0.073 & 0.046 & -0.0008 & -0.460 & 0.484 \\
\hline SW & 1992 & 0.068 & 0.037 & -0.0005 & -0.437 & 0.445 \\
\hline SW & 1995 & 0.076 & 0.041 & -0.0006 & -0.443 & 0.469 \\
\hline SW & 2000 & 0.092 & 0.036 & -0.0005 & -0.392 & 0.471 \\
\hline UK & 1986 & 0.093 & 0.046 & -0.0007 & -0.396 & 0.304 \\
\hline $\mathrm{UK}^{*}$ & 1991 & 0.141 & 0.028 & -0.0004 & -0.405 & 0.187 \\
\hline $\mathrm{UK}^{*}$ & 1994 & 0.156 & 0.028 & -0.0003 & -0.390 & 0.207 \\
\hline $\mathrm{UK}^{*}$ & 1995 & 0.161 & 0.018 & $-.0001 * *$ & -0.368 & 0.204 \\
\hline US & 1969 & 0.087 & 0.028 & -0.0004 & -0.533 & 0.495 \\
\hline US* & 1974 & 0.076 & 0.028 & -0.0004 & -0.390 & 0.345 \\
\hline US* & 1979 & 0.074 & 0.018 & -0.0002 & -0.476 & 0.288 \\
\hline US* & 1986 & 0.092 & 0.035 & -0.0004 & -0.292 & 0.365 \\
\hline US* & 1991 & 0.098 & 0.030 & -0.0004 & -0.275 & 0.405 \\
\hline US* & 1994 & 0.113 & 0.035 & -0.0004 & -0.257 & 0.396 \\
\hline US* & 1997 & 0.118 & 0.034 & -0.0004 & -0.301 & 0.384 \\
\hline US* & 2000 & 0.116 & 0.027 & -0.0003 & -0.307 & 0.384 \\
\hline
\end{tabular}

The dependent variable is hourly wage for countries with *; otherwise the dependent variable is annual earnings.

Coefficients with $* *$ are not statistically significant at $5 \%$ p-value level, otherwise are statistically significant at least $5 \%$ p-value level.

Variable Definitions:

School denotes the rate of return to an additional year of schooling in equation (9);

Potential Experience is experience coefficient in equation (9);

Experience Square is experience square coefficient in equation (9);

Female is the female dummy variable coefficient in equation (9), 1 for female and 0 otherwise;

As computed from equation (23), incomplete Information is expressed as a percentage of potential maximum wages. 
Table 3: Marginal Effect of Covariates on E(U) by Country and Year**

\begin{tabular}{|c|c|c|c|c|c|c|c|}
\hline Country & Year & Female & Married & $\begin{array}{l}\text { Divorced/ } \\
\text { Widowed }\end{array}$ & $\begin{array}{l}\text { Majority } \\
\text { Ethnicity }\end{array}$ & School & $\begin{array}{c}\text { Potential } \\
\text { Experience }\end{array}$ \\
\hline $\mathrm{CN}^{*}$ & 1981 & 0.139 & & & & -0.005 & -0.002 \\
\hline $\mathrm{CN}^{*}$ & 1987 & 0.100 & -0.162 & -0.107 & & -0.106 & -0.006 \\
\hline $\mathrm{CN}^{*}$ & 1991 & 0.135 & -0.077 & -0.143 & & -0.016 & -0.008 \\
\hline $\mathrm{CN}^{*}$ & 1994 & 0.093 & -0.088 & -0.021 & & -0.012 & -0.010 \\
\hline $\mathrm{CN}^{*}$ & 1997 & 0.120 & -0.076 & -0.098 & & -0.007 & -0.011 \\
\hline $\mathrm{CN}^{*}$ & 1998 & -0.049 & -0.057 & 0.060 & & 0.027 & 0.009 \\
\hline $\mathrm{CN}^{*}$ & 2000 & -0.059 & -0.077 & -0.022 & & 0.012 & -0.012 \\
\hline $\mathrm{CZ}$ & 1992 & 0.034 & 0.004 & -0.004 & & -0.002 & -0.015 \\
\hline $\mathrm{CZ}$ & 1996 & 0.073 & -0.026 & -0.006 & -0.119 & 0.004 & -0.010 \\
\hline FI & 1987 & -0.262 & 0.038 & -0.245 & 0.016 & -0.081 & -0.016 \\
\hline FI & 1991 & -0.236 & 0.081 & & 0.018 & -0.076 & -0.034 \\
\hline FI & 1995 & -0.142 & 0.097 & -0.032 & 0.032 & -0.059 & -0.044 \\
\hline FI & 2000 & -0.173 & 0.134 & -0.067 & -0.040 & -0.061 & -0.036 \\
\hline GE* & 1984 & 0.095 & -0.132 & -0.344 & -0.059 & 0.010 & -0.042 \\
\hline GE* & 1989 & 0.165 & -0.045 & 0.142 & 0.059 & 0.014 & -0.039 \\
\hline GE* & 1994 & 0.083 & 0.053 & 0.032 & 0.138 & 0.008 & -0.027 \\
\hline GE* & 2000 & 0.089 & 0.032 & 0.067 & 0.035 & 0.006 & -0.019 \\
\hline $\mathrm{IE}^{*}$ & 1994 & 0.219 & -0.267 & -0.198 & -0.298 & -0.008 & 0.003 \\
\hline IE* & 1995 & 0.170 & -0.270 & -0.041 & -0.258 & -0.008 & 0.001 \\
\hline IE* & 1996 & 0.256 & -0.276 & -0.068 & -0.063 & -0.007 & 0.007 \\
\hline IS & 1992 & 0.132 & -0.042 & 0.005 & -0.162 & 0.034 & -0.001 \\
\hline IS & 1997 & 0.040 & -0.156 & 0.088 & -0.215 & 0.035 & -0.018 \\
\hline NL* & 1983 & 0.069 & -0.236 & -0.389 & & 0.012 & 0.006 \\
\hline NL & 1987 & 0.198 & -0.162 & 0.107 & & 0.015 & 0.009 \\
\hline NL & 1991 & 0.486 & -0.958 & -0.804 & & -0.044 & -0.055 \\
\hline NL* & 1994 & 0.227 & -0.713 & -0.930 & & -0.014 & -0.013 \\
\hline NL* & 1999 & 0.141 & -0.577 & -0.196 & & -0.021 & -0.028 \\
\hline NW & 1991 & -0.230 & 0.031 & 0.429 & & -0.055 & -0.043 \\
\hline NW & 1995 & -0.170 & -0.065 & 0.350 & & -0.054 & -0.050 \\
\hline NW & 2000 & -0.119 & -0.011 & 0.067 & -0.152 & -0.049 & -0.031 \\
\hline SW & 1992 & -0.003 & -0.086 & & -0.184 & -0.025 & -0.006 \\
\hline SW & 1995 & -0.019 & -0.112 & & -0.389 & -0.034 & -0.034 \\
\hline SW & 2000 & 0.086 & 0.031 & 0.119 & -0.336 & -0.003 & -0.058 \\
\hline UK & 1986 & 0.247 & & & & 0.014 & 0.006 \\
\hline $\mathrm{UK}^{*}$ & 1991 & -0.107 & -0.042 & -0.049 & & 0.034 & -0.001 \\
\hline $\mathrm{UK}^{*}$ & 1994 & -0.023 & 0.071 & 0.079 & & 0.050 & 0.004 \\
\hline $\mathrm{UK}^{*}$ & 1995 & -0.058 & -0.020 & -0.005 & & 0.048 & -0.001 \\
\hline US & 1969 & 0.452 & -0.200 & -0.183 & -0.228 & -0.046 & -0.056 \\
\hline US* & 1974 & 0.154 & -0.147 & -0.080 & -0.072 & -0.006 & -0.028 \\
\hline US* & 1979 & -0.015 & & & & 0.005 & -0.002 \\
\hline US* & 1986 & 0.136 & -0.201 & -0.183 & -0.069 & -0.013 & -0.021 \\
\hline US* & 1991 & 0.175 & -0.128 & -0.006 & -0.088 & -0.017 & -0.020 \\
\hline US* & 1994 & 0.134 & -0.134 & -0.005 & -0.067 & -0.012 & -0.020 \\
\hline US* & 1997 & 0.093 & -0.128 & -0.015 & -0.067 & -0.008 & -0.020 \\
\hline US* & 2000 & 0.073 & -0.157 & -0.035 & -0.069 & -0.012 & -0.020 \\
\hline
\end{tabular}

* Denotes computations based on hourly wage; otherwise computation based on with annual earnings.

** Marginal effect for each country year is the average marginal effect of individual workers within that country year.

Definitions of variables in Table 3:

Female is the gender dummy variable in equation (13), 1 for female and 0 otherwise;

Married is the marital status dummy variable in equation (13), 1 for married and 0 otherwise;

Divorced/Widowed is the marital status dummy variable in equation (13), 1 for divorced/widowed and 0 otherwise;

Majority Ethnicity is the race/ethnicity dummy in equation (13), 1 for majority ethnic group and 0 otherwise;

School is the years of schooling variable in equation (13);

Potential Experience is the years of working experience in equation (13), calculated as age-school-6. 
Table 4: Marginal Effect of Covariates on V(U) by Country and Year**

\begin{tabular}{|c|c|c|c|c|c|c|c|}
\hline Country & Year & Female & Married & $\begin{array}{l}\text { Divorced/ } \\
\text { Widowed }\end{array}$ & $\begin{array}{l}\text { Majority } \\
\text { Ethnicity }\end{array}$ & School & $\begin{array}{c}\text { Potential } \\
\text { Experience }\end{array}$ \\
\hline $\mathrm{CN}^{*}$ & 1981 & 0.119 & & & & -0.004 & -0.002 \\
\hline $\mathrm{CN}^{*}$ & 1987 & 0.074 & -0.338 & -0.208 & & -0.029 & -0.014 \\
\hline $\mathrm{CN}^{*}$ & 1991 & 0.190 & -0.117 & -0.209 & & -0.025 & -0.015 \\
\hline $\mathrm{CN}^{*}$ & 1994 & 0.115 & -0.145 & -0.030 & & -0.022 & -0.022 \\
\hline $\mathrm{CN}^{*}$ & 1997 & 0.159 & -0.117 & -0.155 & & -0.016 & -0.026 \\
\hline $\mathrm{CN}^{*}$ & 1998 & 0.004 & 0.076 & 0.067 & & 0.013 & 0.005 \\
\hline $\mathrm{CN}^{*}$ & 2000 & 0.001 & -0.009 & 0.001 & & 0.007 & 0.003 \\
\hline $\mathrm{CZ}$ & 1992 & 0.023 & 0.012 & 0.001 & & -0.002 & -0.020 \\
\hline $\mathrm{CZ}$ & 1996 & 0.062 & -0.005 & 0.004 & -0.107 & -0.002 & -0.017 \\
\hline FI & 1987 & -0.741 & 0.230 & -0.485 & 0.005 & 0.138 & 0.031 \\
\hline FI & 1991 & -0.653 & 0.319 & & 0.000 & -0.127 & -0.006 \\
\hline FI & 1995 & -0.380 & 0.197 & -0.112 & 0.010 & 0.002 & 0.051 \\
\hline FI & 2000 & -0.475 & 0.420 & 0.015 & -0.236 & -0.003 & 0.050 \\
\hline GE* & 1984 & 0.128 & 0.011 & -0.048 & -0.051 & 0.023 & -0.006 \\
\hline $\mathrm{GE}^{*}$ & 1989 & 0.174 & 0.060 & 0.097 & 0.051 & 0.014 & -0.006 \\
\hline GE* & 1994 & 0.099 & 0.093 & 0.097 & 0.130 & 0.016 & -0.001 \\
\hline $\mathrm{GE}^{*}$ & 2000 & 0.116 & 0.171 & 0.145 & 0.047 & 0.003 & -0.001 \\
\hline IE* & 1994 & 0.364 & -0.365 & -0.263 & -0.444 & -0.012 & 0.007 \\
\hline IE* & 1995 & 0.324 & -0.308 & -0.052 & -0.400 & -0.010 & 0.010 \\
\hline IE* & 1996 & 0.545 & -0.450 & -0.097 & -0.148 & -0.012 & 0.019 \\
\hline IS & 1992 & 0.148 & -0.043 & 0.006 & -0.179 & 0.038 & -0.001 \\
\hline IS & 1997 & 0.163 & -0.122 & 0.216 & -0.381 & 0.063 & 0.001 \\
\hline $\mathrm{NL}^{*}$ & 1983 & 0.031 & -0.081 & -0.142 & & 0.005 & 0.003 \\
\hline NL & 1987 & 0.539 & 0.110 & 0.125 & & 0.020 & 0.014 \\
\hline NL & 1991 & 0.978 & -0.343 & -0.211 & & -0.032 & -0.022 \\
\hline $\mathrm{NL}^{*}$ & 1994 & 0.332 & -0.360 & -0.480 & & -0.007 & -0.002 \\
\hline $\mathrm{NL}^{*}$ & 1999 & 0.130 & -0.448 & -0.144 & & -0.017 & -0.022 \\
\hline NW & 1991 & -0.527 & 0.567 & 0.946 & & -0.056 & -0.001 \\
\hline NW & 1995 & -0.352 & -0.071 & 0.278 & & -0.053 & -0.024 \\
\hline NW & 2000 & -0.199 & -0.074 & 0.030 & -0.281 & -0.058 & -0.021 \\
\hline SW & 1992 & 0.003 & -0.167 & & -0.393 & -0.057 & -0.025 \\
\hline SW & 1995 & -0.041 & -0.219 & & -0.761 & -0.048 & -0.041 \\
\hline SW & 2000 & 0.188 & -0.090 & 0.042 & -0.600 & 0.013 & -0.052 \\
\hline UK & 1986 & 0.511 & & & & 0.020 & 0.013 \\
\hline $\mathrm{UK}^{*}$ & 1991 & -0.001 & -0.008 & -0.008 & & 0.014 & 0.002 \\
\hline $\mathrm{UK}^{*}$ & 1994 & 0.015 & 0.079 & 0.080 & & 0.038 & 0.009 \\
\hline $\mathrm{UK}^{*}$ & 1995 & 0.002 & 0.012 & 0.002 & & 0.022 & 0.006 \\
\hline US & 1969 & 0.986 & 0.008 & -0.046 & -0.402 & -0.013 & -0.012 \\
\hline US* & 1974 & 0.210 & -0.206 & -0.112 & -0.099 & -0.009 & -0.039 \\
\hline US* & 1979 & -0.012 & & & & 0.004 & -0.001 \\
\hline US* & 1986 & 0.177 & -0.493 & -0.424 & -0.133 & -0.039 & -0.057 \\
\hline US* & 1991 & 0.429 & -0.213 & -0.018 & -0.146 & -0.006 & 0.001 \\
\hline US* & 1994 & 0.287 & -0.224 & -0.039 & -0.109 & -0.001 & -0.012 \\
\hline US* & 1997 & 0.188 & -0.224 & -0.044 & -0.120 & -0.005 & -0.024 \\
\hline US* & 2000 & 0.154 & -0.244 & -0.085 & -0.109 & -0.004 & -0.011 \\
\hline
\end{tabular}

Data Source: Luxembourg Income Study

* Denotes computations based on hourly wage; otherwise computation based on with annual earnings.

** Marginal effect for each country year is the average marginal effect of individual workers within that country year. Definitions of variables in Table 4:

Female is the gender dummy variable in equation (14), 1 for female and 0 otherwise;

Married is the marital status dummy variable in equation (14), 1 for married and 0 otherwise;

Divorced/Widowed is marital status dummy variable in equation (14), 1 for divorced/widowed and 0 otherwise;

Majority Ethnicity is race/ethnicity dummy variable in equation (14), 1 for majority ethnic group and 0 otherwise;

School is the years of schooling in equation (14);

Potential Experience is the years of working experience in equation (14), calculated by age-school-6. 
Table 5: Statistic Summary of the Variables from the Cross Country Regressions

\begin{tabular}{|c|c|c|c|c|c|}
\hline Variable & $\begin{array}{c}\text { Number of } \\
\text { Observations } \\
\end{array}$ & Mean & $\begin{array}{l}\text { Standard } \\
\text { Deviation }\end{array}$ & Minimum & Maximum \\
\hline $\begin{array}{l}\text { Unemployment Insurance (Expenditure as a } \\
\text { Percentage of GDP }\end{array}$ & 37 & 1.779 & 1.181 & 0.26 & 5.6 \\
\hline Log of Unemployment Insurance & 37 & 0.352 & 0.722 & -1.347 & 1.723 \\
\hline Population Density (People Per sq km) & 45 & $28.542^{*}$ & 147.464 & 2.7000 & 466.499 \\
\hline $\begin{array}{l}\text { Industrial Employment } \quad(\% \text { of } \\
\text { Employment) }\end{array}$ & 42 & 27.764 & 5.644 & 21.5 & 45.1 \\
\hline Rural Population (\% of Total Population) & 45 & 22.107 & 9.822 & 8.841 & 42.283 \\
\hline Inflow of Foreign Worker (in Thousands) & 21 & $77.700^{*}$ & 184.707 & 3.8 & 742.3 \\
\hline $\begin{array}{l}\text { Inflow of Foreign Worker ( } \% \text { of Total } \\
\text { Population) }\end{array}$ & 21 & 0.161 & 0.108 & 0.033 & 0.412 \\
\hline Incomplete Information & 45 & 0.359 & 0.108 & 0.156 & 0.581 \\
\hline Hourly Wage Dummy( 1 for Hourly Wage) & 45 & 0.600 & 0.495 & 0 & 1 \\
\hline Adjusted Incomplete Information & 45 & 0.309 & 0.088 & 0.130 & 0.455 \\
\hline
\end{tabular}

Data Source: Incomplete information is from Table 2; UI is from OECD Employment Outlook; the remaining variables are from World Bank data.

* denotes median. 
Table 6: Regression Results of Country Attributes on Country workers’ Average Incomplete Information of Wages (Robust Standard Error Used; T Value in Parentheses)

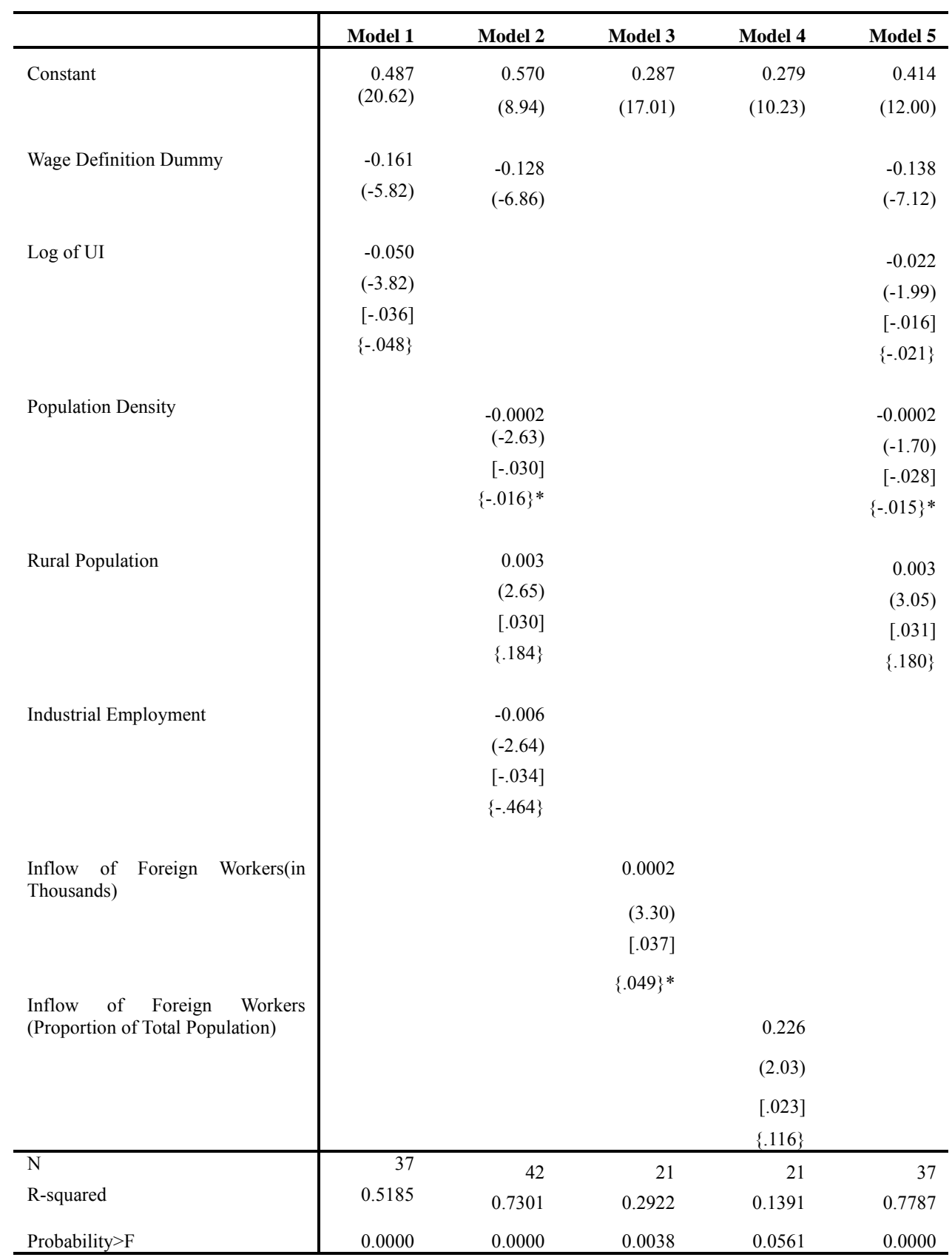

Note: [ ] contains the marginal effect of a standard deviation change in the variable.

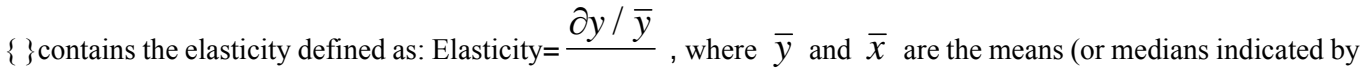
$\partial x / \bar{x}$

*) of the dependent variable and the independent variable respectively. 
Figure 1: Adjusted Incomplete Information versus Logarithm of UI.

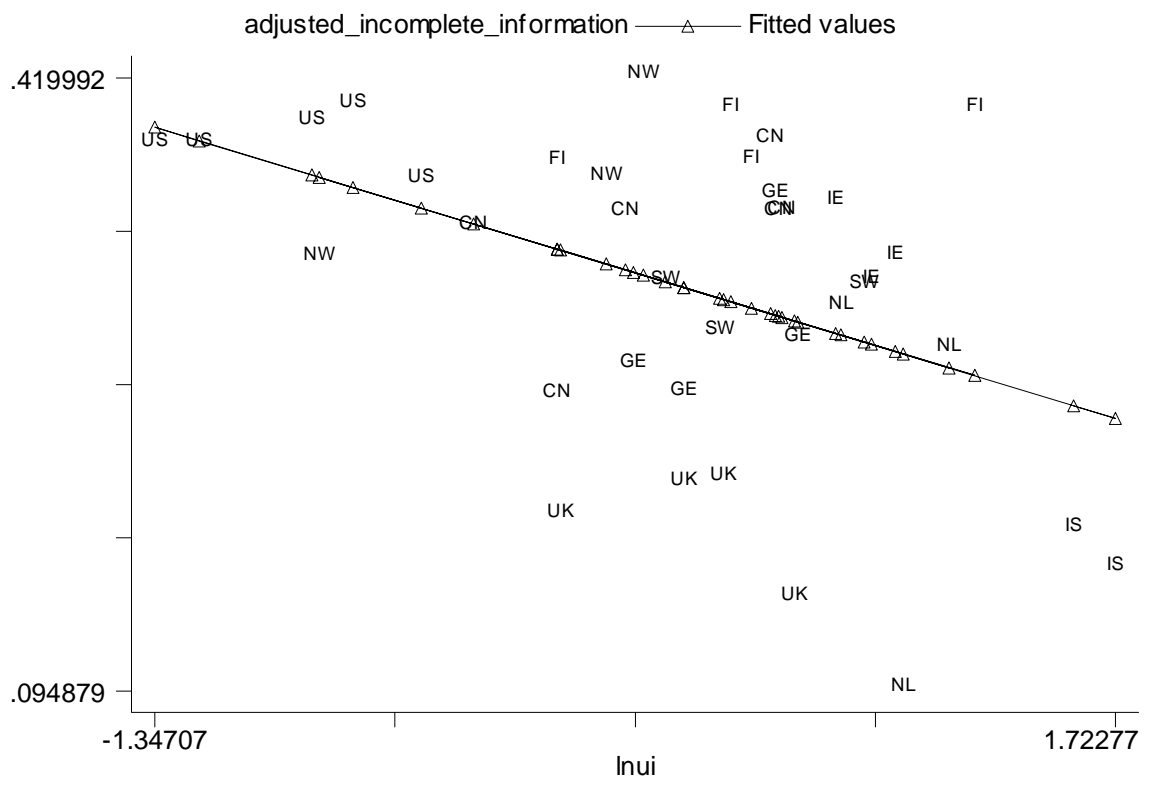

Figure 2: Adjusted Incomplete Information versus Population Density.

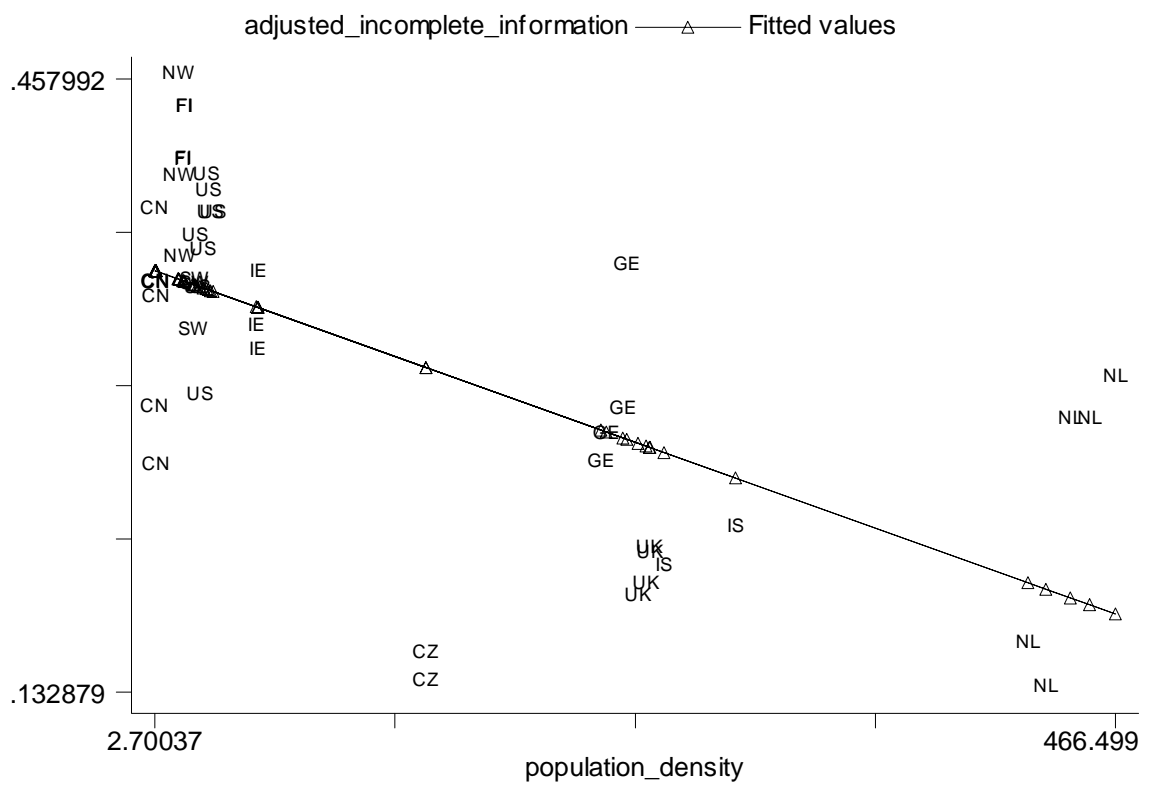


Figure 3: Adjusted Incomplete Information versus Rural Population.

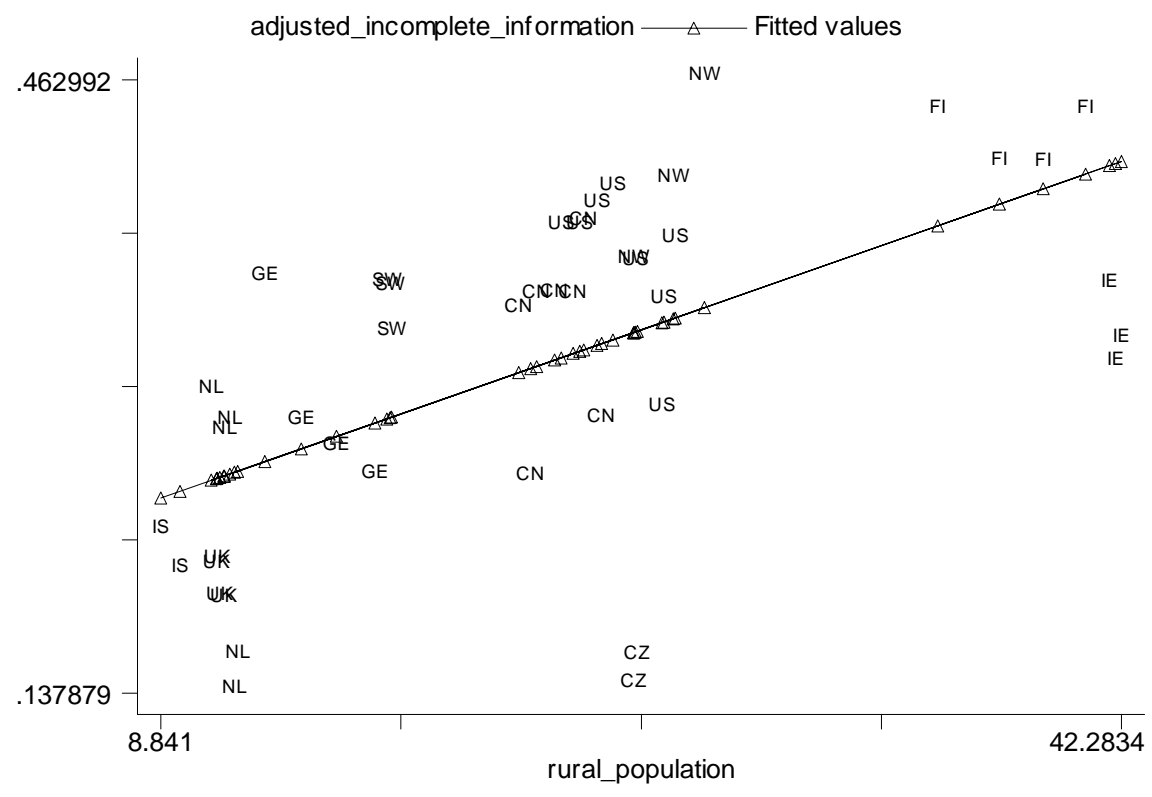

Figure 4: Adjusted Incomplete Information versus Industrial Employment.

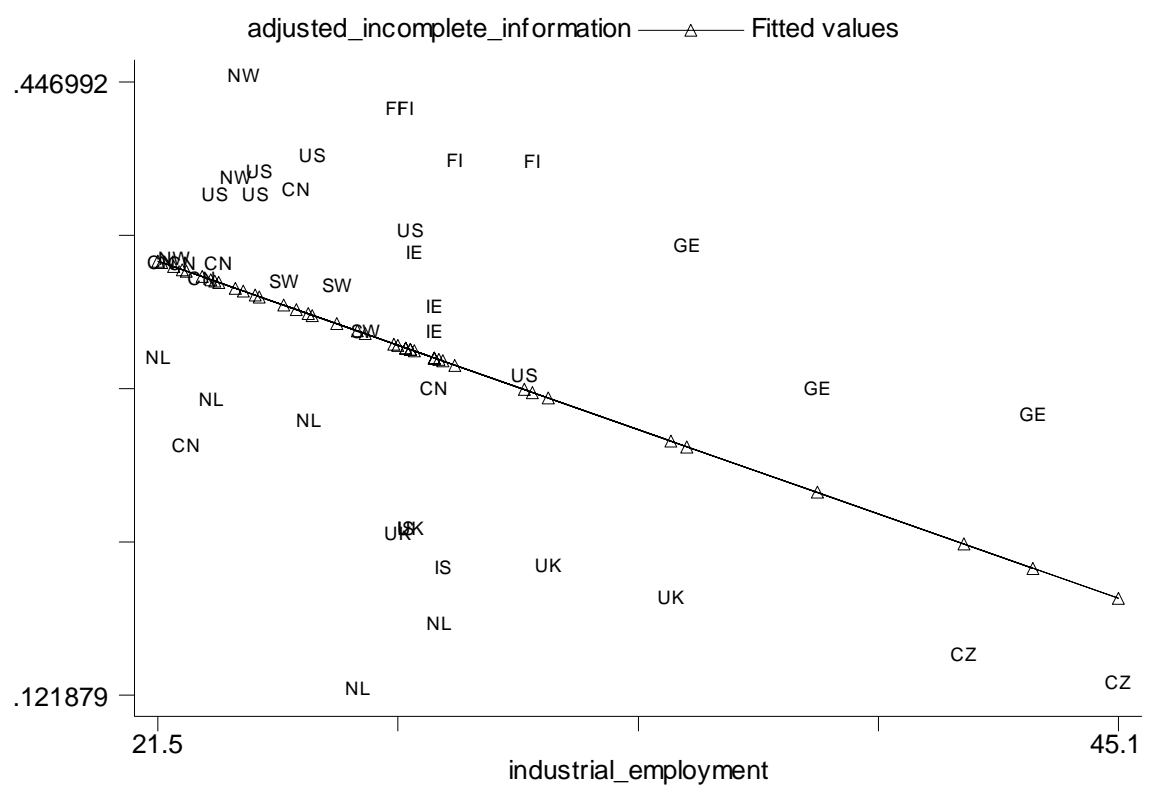


Figure 5: Adjusted Incomplete Information versus Inflow of Foreign Workers

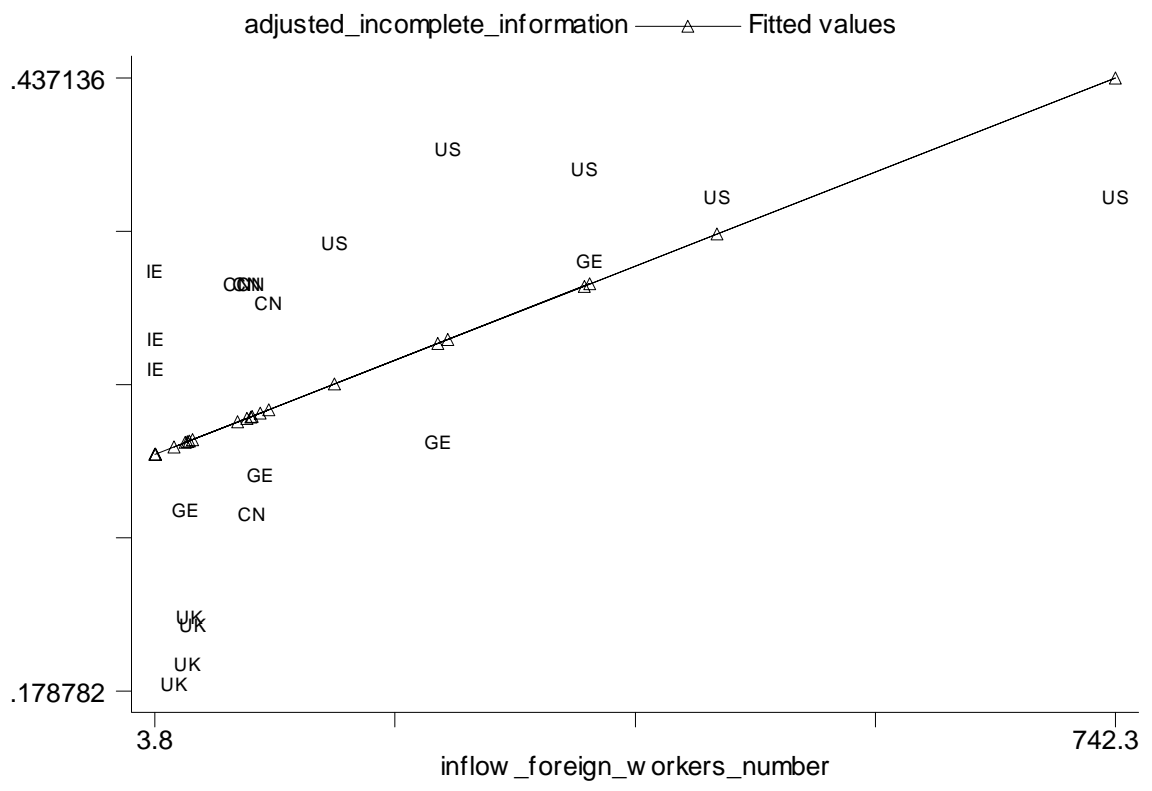

Figure 6: Adjusted Incomplete Information versus Proportional Inflow of Foreign Workers

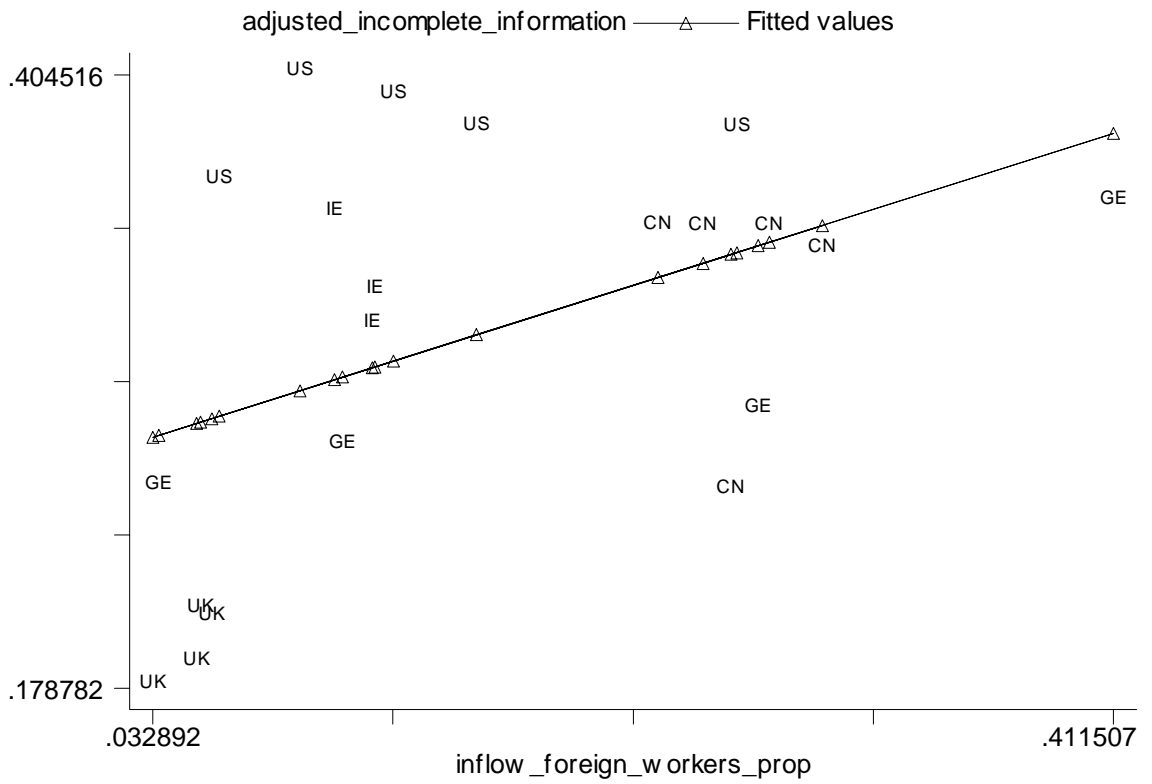




\section{REFERENCES}

Aigner, Dennis, Lovell, C. Knox and Schmidt, Peter (1977) "Formulation and Estimation of Stochastic Frontier Production Function Models,” Journal of Econometrics 6:21-38.

Arellano, Manuel; Bentolila, Samuel ; Bover, Olympia (1998). "Unemployment Duration, Benefit Duration and the Business Cycle," C.E.P.R. Discussion Paper 1840.

Arnold, Michael A. (2000) "Costly Search, Capacity Constraints, and Bertrand Equilibrium Price Dispersion,” International Economic Review 41(1): 117-31.

Beach C. M. and Kaliski, S. (1983) The Impact of the 1979 Unemployment Insurance Amendments," Canadian Public Policy 9: 164-73.

Bester, Helmut (1986) "Bargaining, Search Costs and Equilibrium Price Distribution," University of Bonn, Germany, Discussion Paper Serie A.

Borjas, George (1985) "Assimilation, Changes in Cohort Quality, and the Earnings of Immigrants," Journal of Labor Economics, 3:463-89.

Bound, John and Krueger, Alan B. (1991) "The Extent of Measurement Error in Longitudinal Earnings Data: Do Two Wrongs Make a Right?” Journal of Labor Economics, 9(1): 1-24.

Burdett, Kenneth and Judd, Kenneth L. (1983) “Equilibrium Price Dispersion,” Econometrica 51(4): 955-69.

Card, David and Levine, Phillip B. (1998) "Extended Benefits and the Duration of UI Spells: Evidence from the New Jersey Extended Benefit Program," National Bureau of Economic Research, Inc, NBER Working Papers: 6714.

Chiswick, Barry (1978) "The Effect of Americanization on the Earnings of Foreign Born Men," Journal of Political Economy, 86:897—921.

Chiswick, Barry (1986) "Is the New Immigrant Less Skilled Than The Old?" Journal of Labor Economics 4::897-921.

Daneshvary, Nasser; Herzog, Henry; Hofler, Richard; and Schlottmann, Alan (1992) "Job Search and Immigrant Assimilation: An Earnings Frontier Approach," Review of Economics and Statistics, 74(3): 482-92.

Ehrenberg, Ronald and Oaxaca, Ronald. (1976) "Unemployment insurance, duration of unemployment and subsequent wage gain," American Economic Review: 754-766.

Fougere, D., Pradel, J., and Roger, M. (1998) “The Influence of the State Employment Service on 
the Search Effort and on the Probability of Leaving Unemployment," Institut National de la Statistique et des Etudes Economiques Working Paper.

Freeman, R. (1980) "Unionism and the dispersion of wages," Industrial and Labor Relations Review: 3-23.

Gaynor, Martin and Polachek, Solomon (1994) "Measuring Information in the Market: An Application to Physician Services," Southern Economic Journal 60(4):815-31.

Gong, Byeong-Ho and Sickles, Robin (1992) "Finite Sample Evidence On The Performance Of Stochastic Frontiers And Data Envelopment Analysis Using Panel Data," Journal of Econometrics 51(1-2): 259-284

Gonzalo, Maria Teresa (2002). "A New Look at the UI Effect on Transitions from Unemployment into Wage Employment in Spain: The Limited Duration of the UI Benefits Entitlement," Applied Economics 34(17): 2177-87.

Groot, Wim and Oosterbeek, Hessel (1994) "Stochastic Reservation and Offer Wages," Labour Economics 1(3/4): 383-90.

Ham, John and Rea, Samuel (1987) "Unemployment Insurance and Male Unemployment Duration in Canada," Journal of Labor Economics 5(3): 325-53.

Heckman, James and Solomon Polachek (1974). "Empirical Evidence on the Functional Form of the Earnings-Schooling Relationship," Journal of the American Statistical Association, 69: 350-54

Hofler, Richard and Murphy, Kevin J. (1992) "Underpaid and Overworked: Measuring the Effect of Imperfect Information on Wages," Economic Inquiry, 30(3): 511-29.

Hofler, Richard and Polachek, Solomon. (1985) “A New Approach for Measuring Wage Ignorance in the Labor Market," Journal of Economics and Business: 267-276.

Jurajda, Štěpán and Tannery, Frederick J. (2003) "Unemployment Durations and Extended Unemployment Benefits in Local Labor Markets," Industrial and Labor Relations Review 56(2): 324-48.

Kamiya, Kazuya and Sato, Takashi (2004) "Equilibrium Price Dispersion in a Matching Model with Divisible Money," International Economic Review 45(2): 413-30.

Katz, Eliakim and Ziderman, Adrian (1986) "Incomplete Information, Non-wage Benefits and Desirable-Worker Self Selection,” Australian Economic Papers 25(47): 252-56

Kumbhakar, Subal and Lovell, C. A. Knox. (2000). Stochastic Frontier Analysis. Cambridge 
University Press.

Lach, Saul and Tsiddon, Daniel (1992) "The Behavior of Prices and Information: An Empirical Analysis of Dissaggregated Price Data," Journal of Political Economy, 100(2): 349-389.

Lang, Guenter (2004) "How Different Are Wages from Wage Potentials? Analyzing the Earnings Disadvantage of Immigrants in Germay," Institute for Economics Discussion Paper \#256, Universitaet Augsburg.

McCall, John (1970) "Economics of Information and Job Search," Quarterly Journal of Economics, 84:113-26.

McCall, John (1973) Income Mobility, Racial Discrimination and Economic Growth. Lexington: D.C. Health.

Meeusen, W. and van den Broeck, J. (1977) "Efficiency Estimation form Cobb-Douglas Production Functions and Composed Errors," International Economic Review 18(2): 434-44.

Meyer, Bruce (1990) “Unemployment Insurance and Unemployment Spells," Econometrica 58(4): 757-82.

Micklewright, John and Nagy, Gyula (1995) "Unemployment Insurance and Incentives in Hungary," C.E.P.R. Discussion Papers, CEPR Discussion Papers: 1118.

Mincer, Jacob. (1974). Schooling, Experience and Earnings. New York: Columbia University Press for the NBER.

Moffitt, Robert and Nicholson, Walter (1982) "The Effect of Unemployment Insurance on Unemployment: The Case of Federal Supplemental Benefits," Review of Economics and Statistics 64(1): 1-11.

Mortenson, Dale (1970) "Job Search, the Durationof Unemployment, and the Phillips Curve," American Economic Review, 60(5): 847-62.

Murphy, Kevin and Welch, Finis (1990) "Empirical Age-Earnings Profiles," Journal of Labor Economics, 8(2): 202-29.

Nelson, Phillip (1970) "Information and Consumer Behavior," Journal of Political Economy, 78:311-29.

Olson, Jerome, Schmidt, Pter, and Waldman Donald (1980) "A Monte Carlo Study of Estimators of Stochastic Frontier Production Functions,” Journal of Econometrics 13(1): 67-82.

Polachek, Solomon (2004) "What Can We Learn About the Decline in Union Membership From 
International Data?" in Changing Roles of Unions: New Forms of Representation, P. Wunnava, ed. (Armonk, NY: M.E. Sharpe), pp. 362-377.

Polachek, Solomon and Horvath, Francis (1977) "A Life Cycle Approach to Migration: Analysis of the Perspicacious Peregrinator," Research in Labor Economics 1:103-49.

Polachek, Solomon and Robst, John (1998) "Employee Labor Market Information: Comparing Direct World Of Work Measures Of Workers' Knowledge To Stochastic Frontier Estimates," Labour Economics: 231-242.

Polachek, Solomon and Yoon, Bong Joon (1987) “A Two-Tiered Earnings Frontier Estimation of Employer and Employee Information in the Labor Market," Review of Economics and Statistics, 296-302.

Polachek, Solomon and Yoon, Bong Joon (1996) "Panel Estimates of a Two-Tiered Earnings Frontier," Journal of Applied Econometrics, 11(2): 169-178.

Reinganum, Jennifer F. (1980) “A Simple Model of Equilibrium Price Dispersion," Journal of Political Economy 87(4): 851-58

Royston, P. (1991) “Comment on sg.3 and An Improved D'Agostino Test,” Stata Technical Bulletin, 3:23-24.

Sandell, Steven. (1980) "Job search by unemployed women: Determinants of the asking wage," Industrial and Labor Relations Review: 368-378.

Schmidt, P. and Lin, T. (1984) "Simple Tests pf Alternative Specifications in Stochastic Frontier Models," Journal of Econometrics, 24(3): 349-361.

Sorensen, Alan T. (2000) "Equilibrium Price Dispersion in Retail Markets for Prescription Drugs," Journal of Political Economy 108(4): 833-50.

Stata Corporation (2001) Stata Statistical Software: Release 7.0. Reference Annual (College Station: Texas), pp 226-228.

Stephenson, S.P. (1976) “The Economics Of Youth Job Search Behavior,” Review of Economics and Statistics: 104-111.

Stevenson, R.E. 1980. "Likelihood Functions for Generalized Stochastic Frontier Estimation," Journal of Econometrics 13(1): 57-66.

Stigler, George (1961) "The Economics of Information," Journal of Political Economy, 69(3): 213-25. 
Stigler, George and Kindahl, James (1970) The Behavior of Industrial Prices New York: Columbia University Press.

Taubman, P. (1976) "The determinants of earnings: Genetics, family, and other environments; A study of white male twins," American Economic Review: 858-870.

Van Hoomissen, Theresa (1988), "Price Dispersion and Inflation: Evidence From Israel," Journal of Political Economy 1303-14.

van den Berg, Gerard J, and van der Klaauw, Bas (2001) "Counselling and Monitoring of Unemployed Workers: Theory and Evidence from a Controlled Social Experiment," C.E.P.R. Discussion Papers, CEPR Discussion Paper \# 2986.

Wang, Hung-Jen. (2002) "Heteroscedasticity and Non-Monotonic Efficiency Effects of a Stochastic Frontier Model," Journal of Productivity Analysis: 18(3):241-253.

Weinstein, M.A. (1964) "The Sum of Values of A Normal and A Truncated Normal Distribution," Technometrics 6:104-5. 